\title{
Pliocene-Pleistocene ash-fall tuff deposits in the intermountain Humahuaca and Casa Grande basins, northwestern Argentina: tracers in chronostratigraphic reconstructions and key to identify their volcanic sources
}

\author{
*Beatriz Coira ${ }^{1}$, Claudia I. Galli ${ }^{1,2}$, Suzanne Mahlburg Kay ${ }^{3}$, \\ Daniel F. Stockli ${ }^{4}$, Patrocinio Flores ${ }^{5}$, Emilio Eveling ${ }^{2}$
}

\author{
${ }^{I}$ Instituto de Ecorregiones Andinas (INECOA), CONICET-Universidad Nacional de Jujuy, Avda. Bolivia 1661, (4600) S.S. de Jujuy, \\ Argentina. \\ bcoira2015@gmail.com \\ 2 Facultad de Ciencias Naturales, Universidad Nacional de Salta, Avda. Bolivia 5150, 4400 Salta, Argentina. \\ cgalli1801@gmail.com; emilioe145@gmail.com \\ 3 Departments of Earth and Atmospheric Sciences, Cornell University, Ithaca, NY14853, USA. \\ smk16@cornell.edu \\ ${ }^{4}$ Department of Geological Sciences, Jackson School of Geosciences, University of Texas at Austin, 2275 Speedway Stop C9000 \\ Austin, TX 78712-1722, Texas, USA. \\ stockli@jsg.utexas.edu \\ 5 Instituto de Geología y Minería, Universidad Nacional de Jujuy, Avda. Bolivia 1661, (4600) S.S. de Jujuy, Argentina. \\ patro@idgym.unju.edu.ar \\ * Corresponding author: bcoira2015@gmail.com
}

\begin{abstract}
Ash-fall tuffs of the Pliocene-Pleistocene deposits of Humahuaca and Casa Grande intermountain basins, northwestern Argentina, have been differentiated into two groups based on new geochemical and geochronological data which correspond to the tuffs of the Pliocene-Lower Pleistocene alluvial fan deposits dominated by debris flow, deep sandy gravel braided, and shallow ephemeral lake deposits (Uquia and Mal Paso formations), and those recorded in Pleistocene alluvial fans sheet flood deposits. The two clusters of ages recognized: 4.3 to $2.6 \mathrm{Ma}$, and 2.2-pre 0.8 Ma, corresponding to these tuff groups, are in agreement with pulses of ignimbrite eruptions in the Altiplano Puna Volcanic Complex (APVC), and Southerm Puna calderas located west of the study region. The ash-fall tuffs of both groups are mainly vitreous to phenocryst-poor of rhyodacite-dacite composition with minor andesites to trachyandesites, characterized by $58-69 \% \mathrm{SiO}_{2}$ contents, $\mathrm{A} / \mathrm{CNK} 1-1.4, \mathrm{FeO} / \mathrm{MgO}(0.8-2.8)$, which plot in the calc-alkaline range. They can be differentiated based on its immobile trace elements ratios as indicated by a slight enrichment in LREE, higher arc affiliation and somewhat higher $\mathrm{Sm} / \mathrm{Yb}$ ratios in the case of the younger group, although in both $\mathrm{Sm} / \mathrm{Yb}$ ratios are indicative of sequestration of HREE in residual hornblende. The new geochemical and geochronological data of those ash fall tuffs point to these as chrono-stratigraphic tracers of the Humahuaca and Casa Grande intermountain basins stratigraphy, during the Pliocene-Pleistocene, also as the key to identify their volcanic sources.
\end{abstract}


RESUMEN. Depósitos de toba de ceniza del Plioceno-Pleistoceno en las cuencas de intermontanas de Humahuaca y Casa Grande, noroeste de Argentina: trazadores en reconstrucciones cronoestratigráficas y claves para identificar sus fuentes volcánicas. Las tobas de caídas de ceniza hospedadas en los depósitos del Plioceno-Pleistoceno de las cuencas intermontanas de Humahuaca y Casa Grande, noroeste de Argentina, han sido diferenciadas en dos grupos con base en los nuevos datos geoquímicos y geocronológicos obtenidos. Ellos se corresponden con las tobas registradas en depósitos pliocenos de un sistema fluvial entrelazado, asociado a abanicos aluviales y en algunos sectores a acumulaciones lacustres (formaciones Uquia y Mal Paso) con edades de 4,3 a 2,6 Ma, y con aquellas presentes en depósitos pleistocenos de abanicos aluviales de inundación, datados en 2,2 - pre 0,8 Ma. Ambos grupos de edades concuerdan con eventos eruptivos ignimbríticos del Complejo Volcánico del Altiplano-Puna (CVAP) y del Complejo Volcánico de Retroarco de la Puna, localizados al oeste de la región de estudio. Los dos grupos de tobas son vítreas a pobres en fenocristales, de composición riodacítica a dacítica con menores andesitas a traquiandesitas, caracterizadas por contenidos de 58-69\% de $\mathrm{SiO}, \mathrm{A} / \mathrm{CNK}$ $1-1,4, \mathrm{FeO} / \mathrm{MgO}(0,8-2,8)$, que se encuadran en el campo calco-alcalino. Se pueden diferenciar entre ellas en función de sus razones de elementos traza inmóviles, como lo indica un ligero enriquecimiento en LREE, mayor filiación de arco y razones algo más altas de $\mathrm{Sm} / \mathrm{Yb}$, en el caso del grupo más joven, aunque en ambas las razones $\mathrm{Sm} / \mathrm{Yb}$ son indicativas de retención de HREE en hornblenda residual. Los nuevos datos geoquímicos y geocronológicos de esas tobas de caída de ceniza, señalan a estas como trazadores cronoestratigráficos en la estratigrafía de las cuencas intermontanas de Humahuaca y Casa Grande durante el Plioceno-Pleistoceno, así como claves para identificar sus fuentes volcánicas.

Palabras clave: Tobas de caída, Plioceno-Pleistoceno, Cuenas intermontanas, Humahuaca-Casa Grande, Noroeste Argentina.

\section{Introduction}

In the Humahuaca and Casa Grande intermountain basins, Northwestern Argentina (Fig. 1), there are important records of ash-fall tuffs interspersed in their conspicuous Pliocene-Pleistocene sedimentary rock sequences. The characterization of these tuffs offer the possibility to analyze the use of these regional extended and well preserved ash-fall tuffs as chrono-stratigraphic tracers. In this study, we present new petrographic and geochemical (major and trace elements) data and geochronological age constraints from selected ash-fall tuffs from Uquía and Mal Paso formations and from Pleistocene alluvial fans sheetflood deposits outcropping in those basins.

The sedimentary rocks of the Uquía Formation exposed in the Quebrada de Humahuaca (Fig. 1), records numerous taxons of fossil mammals belonging to different lineages that have been used to document major events associated with the Great American Biotic Interchange (GABI) in South America during Pliocene and Early Pleistocene (Reguero et al., 2007; Reguero and Candela, 2008), and become a crucial unit in the calibration of the Uquía South America Land Mammal Age (SALMA) (Marshall et al., 1982). This formation (Upper Pliocene-Lower Pleistocene) is also a carrier of well-preserved levels of tuffs widely distributed along the Quebrada de Humahuaca.

The Mal Paso Formation (Fernández et al., 1973), time-equivalent to the Uquía Formation (Fig. 2), also registers frequent tuff levels and has a large areal extent in the Casa Grande basin (Fig. 1). A decrease in the pyroclastic contribution to the Humahuaca basin is recorded in the Pleistocene alluvial fan deposits distributed in it.

Those well-preserved pyroclastic layers, recorded in these Pliocene-Pleistocene sedimentary sequences, provides the opportunity to investigate their possible sources, as well as their applicability in stratigraphic correlations.

In the particular case of the Uquia Formation, considering the central role it has had in the calibration of the Uquia South American Land Mammal Age: SALMA (Reguero et al., 2007), the study and characterisation of its numerous tuff records becomes important for correlation purposes to extend even beyond the Quebrada de Humahuaca and Casa Grande to Bolivia where similar fossil records have been recognised in the Incahuasi Viscachani and Ayo Ayo regions (MacFadden et al., 1993).

The new petrographic, geochemical and geochronological data determined for the selected ash-fall tuff deposits, combined with previously published studies of the Southern Central Andes ignimbrite centers (de Silva, 1989a, b; Wörner et al., 1992, 1994, 2000; Schröder and Wöerner, 1996; Lindsay et al., 2001; Schmitt et al., 2001; Mamani et al., 2010; Folkes et al., 2011; Kay et al., 2010, 2011; Salisbury et al., 2011, and references therein) are used to analyze possible connections between those tuff and the ignimbrite flare-up that took place 


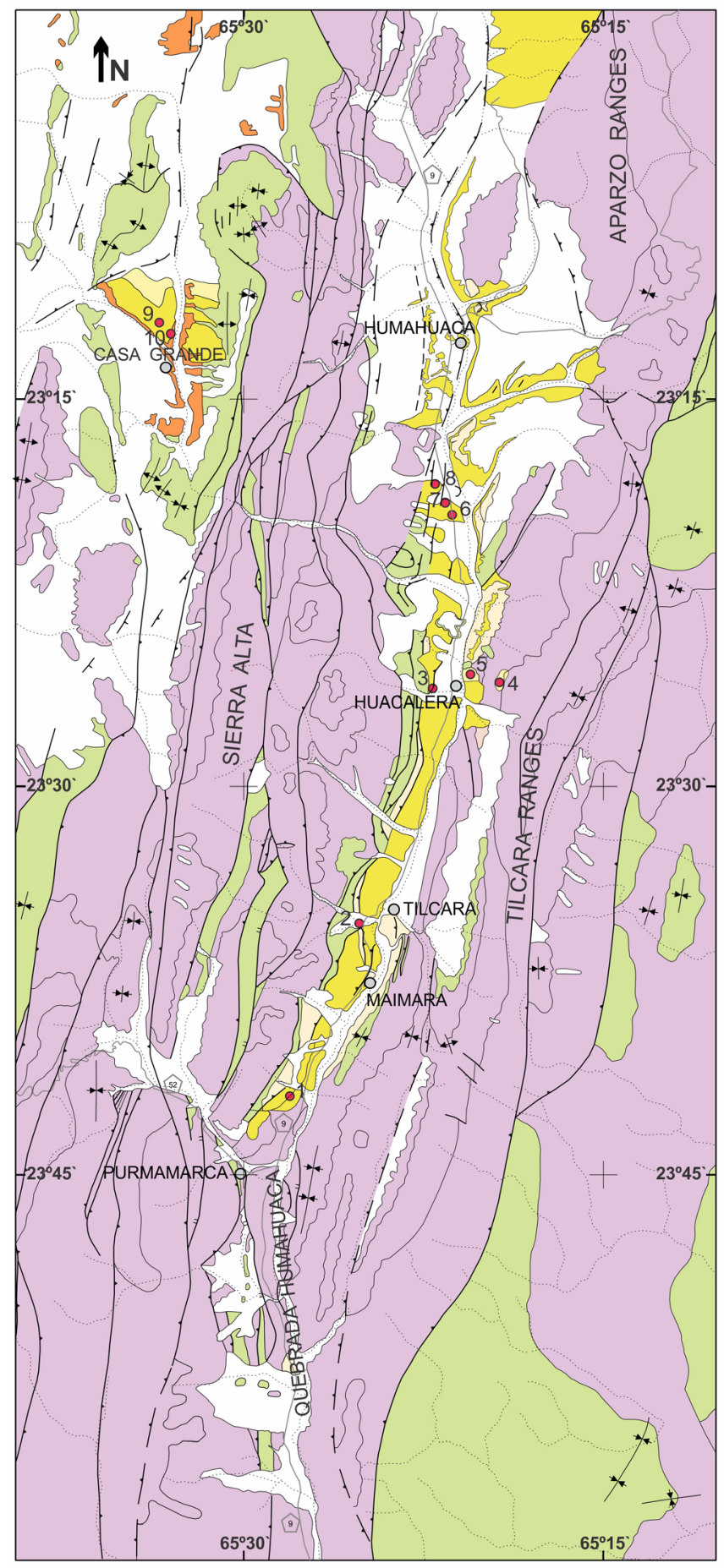

Holocene deposits

Pleistocene deposits

Uquia and Mal Paso Formations (Uppe Pliocene-Lower Pleistocene)

Maimará Formation (Upper Miocene -Lower Pliocene)

Eocene Lower Pliocene deposits

Salta Group (Cretaceous- Paleogene)

Pre-Cretaceous Basament

+ Anticline $\_$Fault

+ Sincline

- Location Studied Profiles

1- Incahuasi

2- Huichaira

3- Quitiacara

4- Alonso

5- El Molino

6- Esquina Blanca South

7- Esquina Blanca North

8- San Roque

9- Casa Grande

10- Casa Grande-Quebrada Salida

FIG. 1. Geologic Map of the Humahuaca-Casa Grande basins. The red dots show the location of the studied profiles. 


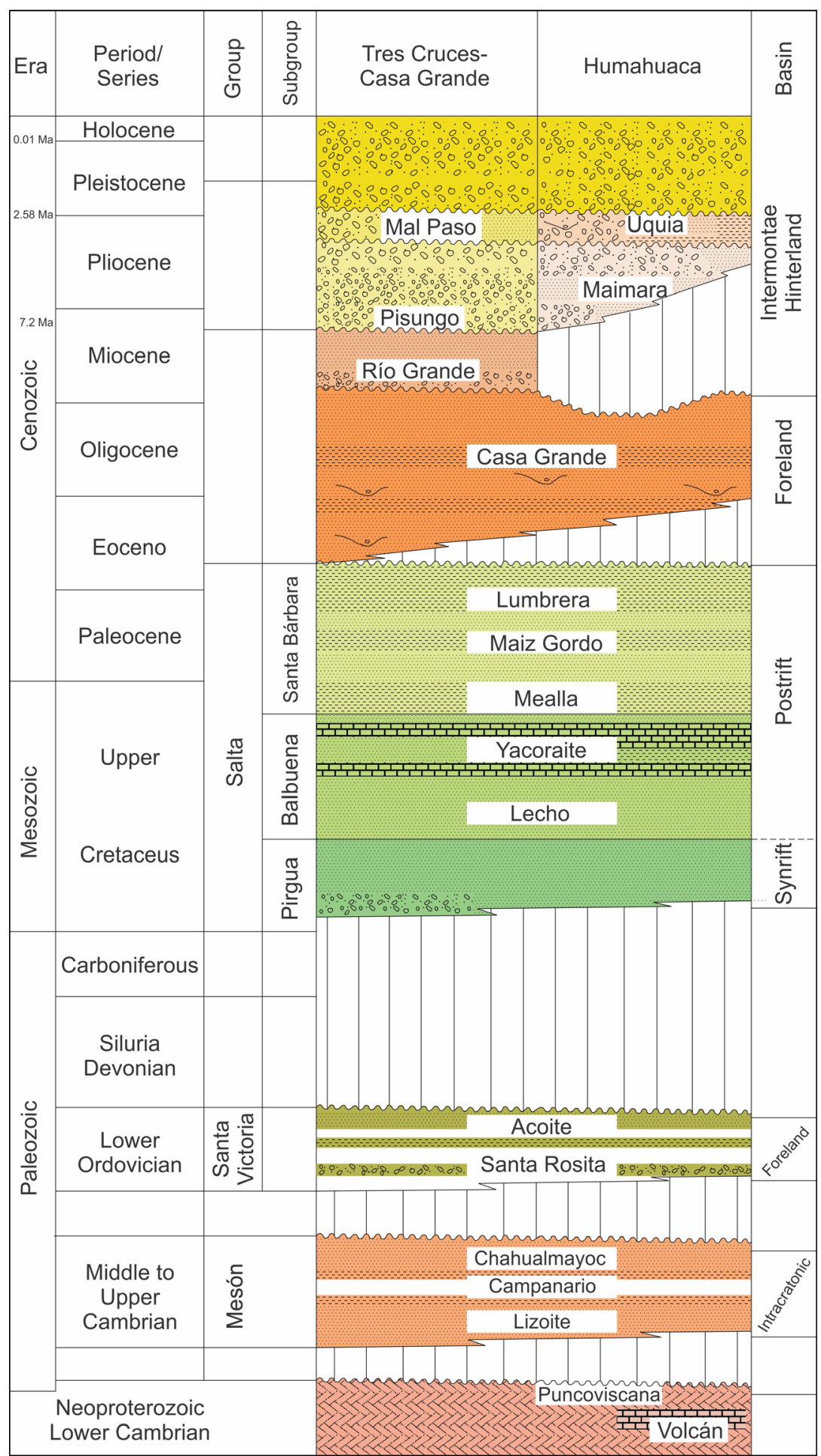

FIG. 2. Lithostratigraphic column of the Humahuaca and Casa Grande intermoutain basins area. The sedimentary fill of both basins is shown and the similar stratigraphic position of the Uquia and Mal Paso formations. The formations that constitute the pre-Miocene basement of both basins are also indicated. 
during Pliocene-Pleistocene to the west-northwest in the Altiplano-Puna Volcanic Complex (APVC, de Silva,1989a), and to the southwest in southern Puna.

\section{Geological setting of the Pliocene-Pleistocene sedimentary rock sequences and its ash-fall tuff deposits at Humahuaca and Casa Grande basins}

The Uquía Formation crops out along the Quebrada de Humahuaca in the Eastern Cordillera, at an elevation of $\sim 2800 \mathrm{~m}$. The rocks of this Formation, defined by De Carles in Castellanos (1950), are gently folded and faulted and unconformable overlies (Fig. 2) the undifferentiated rocks of Puncoviscana Formation (Neoproterozoic-Lower Cambrian), Meson Group (Lower Cambrian-Upper Cambrian), Santa Victoria Group (Ordovician) and continental deposits of Pirgua Subgroup (Cretaceous) and Maimará Formation (Upper Miocene), (Fig. 2). The Uquía Formation is made up of $\sim 70-300 \mathrm{~m}$ of sandstones, siltstones and conglomerates and intercalated whitish, grayish and white-brownish ash-fall tuffs of variable thicknesses (0.10-2 $\mathrm{m})$. These deposits accumulated in a braided river system associated with alluvial fans and in some areas, transitioning into lake accumulations (Galli et al., 2012, 2017; Herrera Oviedo et al., 2017).

Based on paleomagnetic and geochronological studies of the Uquía Formation, ash-fall tuffs in the Esquina Blanca locality were assigned an age of $2.86 \mathrm{Ma}$ (Marshall et al., 1982). Moreover, Walther et al. (1998) determined a zircon fission track age of 2.5 Ma for a dacitic tuff in the laminated mudstone and siltstone deposits, of the upper Uquía Formation in the San Roque profile (Fig. 3), like the $2.55 \mathrm{Ma}$ ${ }^{40} \mathrm{Ar} /{ }^{39} \mathrm{Ar}$ age. In addition Pingel et al. (2013) dated tuffs interbedded with sandstones deposits in the Incahuasi sector in 4.3 to $3.52 \mathrm{Ma}$ (U-Pb zircon ages) and those interstratified with conglomerates in the Quitiacara profile (Fig. 3) in 4.38-4.24 Ma (U-Pb zircon ages).

South of the town of Tilcara (Fig. 1), in the Quebrada de Humahuaca, Pingel et al. (2013) defined the Tilcara Formation which includes conglomerate and fanglomerate deposits interstratified with sandstone and some pyroclastic beds. It reaches a thickness of $\sim 250 \mathrm{~m}$ and unconformably overlies the Maimará Formation rocks. The Tilcara Formation, appears to be contemporaneous with the Uquía Formation, based on tuffs that yield U-Pb zircon ages between 4.2 to $2.5 \mathrm{Ma}$ (Pingel et al., 2013).
In the Alonso locality, on the east side of the Quebrada de Humahuaca (Fig. 1), outcrops a thick succession ( 100-300 m) of alluvial fan sheet flood deposits containing ash fall tuff levels (Fig. 3) giving U-Pb ages of 2.21 Ma (Pingel et al., 2015) and $2.08 \mathrm{Ma}$ (this paper). It is bounded by clear unconformities at the base with Precambrian or Paleozoic-Mesozoic basement and at the top with upper Pleistocene deposits, dated at $0.87 \mathrm{Ma}$ (U-Pb zircon age, Streit et al., 2015) in the El Molino profile (Fig. 3).

The ash-fall tuffs in the Mal Paso Formation yielded in Casa Grande basin U-Pb zircons ages (Streit et al., 2015) of 3.74 $\pm 0.4 \mathrm{Ma}$ (northern basin) and $2.95 \pm 02 \mathrm{Ma}$ and $2.13 \pm 0.08 \mathrm{Ma}$ (central basin). In this basin, the Mal Paso Formation unconformable overlies different units, including the Casa Grande, Río Grande and Pisungo Formations as well as Cretaceous deposits of the Salta Group (Fig. 2). Ages for the tuffs from these Pliocene-Pleistocene sequences previously described fall into two distinct clusters corresponding to eruptive pulses, with one ranging from 4.3 to $2.6 \mathrm{Ma}$ in the case of Uquía and Mal Paso Formations tuffs and one giving ages from 2.21 to $2.10 \mathrm{Ma}$, which corresponds to tuffs in alluvial fans sheet flood deposits.

\section{Methodology}

In order to evaluate the use of the regional extended and well preserved Pliocene-Pleistocene ash-fall tuffs in the Humahuaca and Gasa Grande basins as chronostratigraphic tracers and to analyze their potential sources, we proceeded to investigate its geochronological, mineralogical, petrographic and geochemical characteristics.

Ash-fall tuffs were sampled from stratigraphic sections studied in detail (1:500 or 1:100 scale) at Esquina Blanca South, Esquina Blanca North, San Roque, Incahuasi, Quitiacara, Molinos and Alonso in the Humahuaca Basin and at Quebrada Salida and Casa Grande river in the Casa Grande Basin (Fig. 3, Table 1).

We carried out careful field observations and stratigraphic section measurements of the volcanosedimentary sequences in order to collect tuff samples that showed depositional features indicative of either primary air-fall deposition (e.g., homogeneous deposits with few or no internal structures or with normally graded stratification, in some cases reversely 
בั

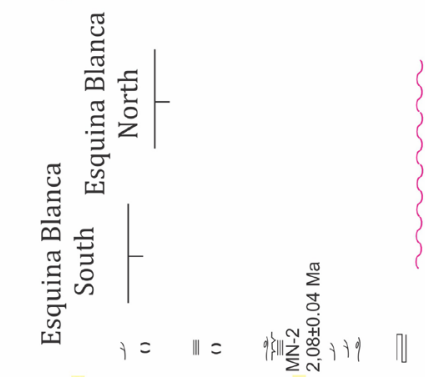

\begin{tabular}{l|l}
0 \\
0 \\
0
\end{tabular}
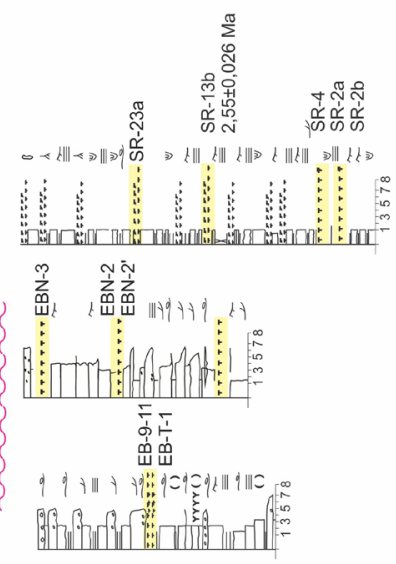

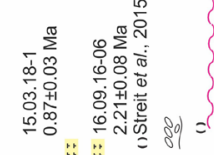

$\stackrel{\Xi}{\sum_{\text {Ix }}^{0}} \mid$

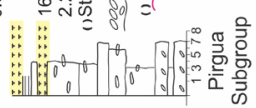

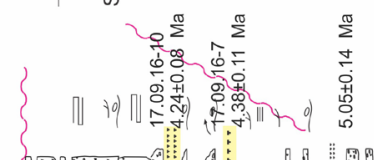

긍

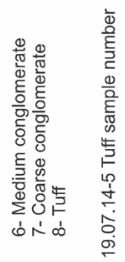
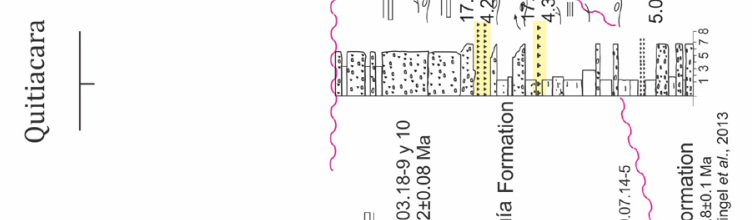

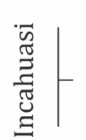

||
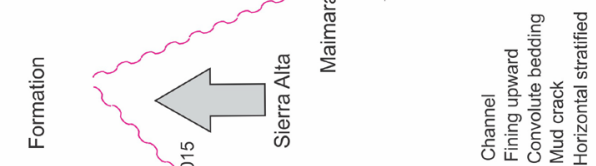

o) -7$\}$ |

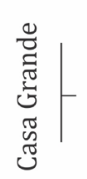

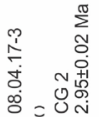

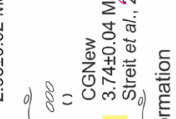

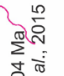

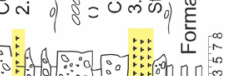

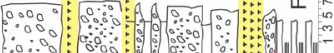
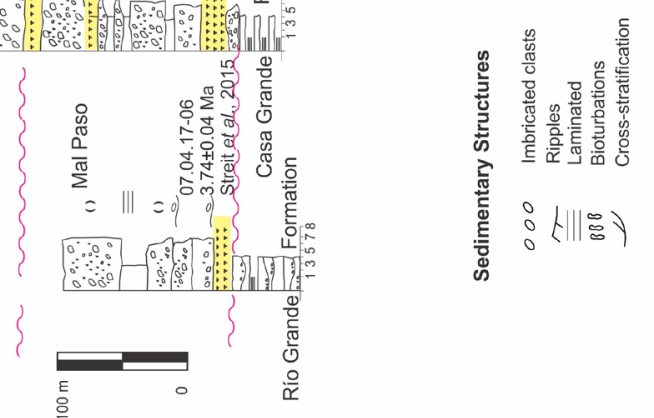
graded) or syn-eruptive re-sedimentation (e.g., compositionally uniform layers or with systematically varying structures that indicate rapid deposition, texturally unmodified juvenile clasts, paucity of lithic clasts, and homogeneity in phenocrystals, according to McPhie et al., 1993). Deposits with evidence of post-eruptive sedimentary mixture, reworking and incorporation of previously lithified ash layers were excluded. Detailed microscopic, petrographic and textural analysis of the collected samples was carried out looking for select the ash fall tuffs free of alteration, homogeneous mineral phases and lacking mixed-in vitroclasts.

The selected samples, as whole rock, have been analyzed by X Ray fluorescence (XRF), Neutron activation (INAA), ICP-AES and ICP-MS. The $\mathrm{XRF}$ analyses of major and trace elements were performed at the Laboratory of the Institute of Geology and Mining, University Nacional de Jujuy on a Rigaku FX 2000 spectrometer with Rh tube. For major element analysis homogenized samples were pulverized and fused with lithium tetraborate flux. $\mathrm{Ba}, \mathrm{Sr}, \mathrm{Rb}, \mathrm{Zr}, \mathrm{Nb}, \mathrm{Hf}, \mathrm{Y}$, Th and $\mathrm{U}$ determinations were performed on rock powder pellets mixed with methacrylate and pressed at $20 \mathrm{t}$. Operating conditions were $50 \mathrm{kV}$ and $45 \mathrm{~mA}$. Major and trace elements were calibrated against standards from US Geological Survey and Japan Geological Survey. Trace elements compositions were analyzed by INAA in the Ward Laboratory at Cornell University following the methods described by Kay et al. (1987) and by ICP-AES and ICP-MS at ALS Laboratories, employing the ultra-trace method described by ALS Geochemistry (2019) (For all geochemical data see Table 2A and 2B).

${ }^{40} \mathrm{Ar} /{ }^{39} \mathrm{Ar}$ analysis on biotite separates from a sample (SR 13b) in the middle section of the stratigraphic profile of San Roque (Fig. 3) was completed at the Geochronology Laboratory of University of Alaska Fairbanks. The samples were irradiated in reactor of McMaster University in Hamilton, Ontario, Canada for 20 megawatt-hours. Taylor Creek Rhyolite standard (TCR-2: 28.619 Ma - Renne et al., 2010) was co-irradiated and used as a neutron flux monitor and to calculate the irradiation parameter $(J)$ for all samples. Upon their return from the reactor, the sample and monitors were loaded in an ultra-high vacuum extraction line. The monitors were fused, and samples were step-heated, following the technique described in Benowitz et al. (2014).
The evolved gases were analyzed using a VG-3600 mass spectrometer at the Geophysical Institute of University of Alaska Fairbanks. The argon isotopes measured were corrected for system blank and mass discrimination, as well as calcium, potassium and chlorine interference reactions following procedures outlined in McDougall and Harrison (1999).

Laser Ablation Inductively Coupled Plasma Mass Spectrometry (LA-ICP-MS) U-Pb dating of zircon from sample MN2 from the Alonso profile (Fig. 3) were carried out the UTChron Laboratory at the University of Texas. We determined the ages of 40 unpolished zircon grains by zircon $\mathrm{U}-\mathrm{Pb}$ depth profile analysis using a single collector Element2 HR-ICP-MS with attached Analyte2 Photon Machine Excimer laser, employing a laser spot of $30 \mu \mathrm{m}$ with $10 \mathrm{~Hz}$ frequency and a fluence of $6 \mathrm{~J} / \mathrm{cm}^{2}$. GJ1 was used as primary zircon standard $\left({ }^{206} \mathrm{~Pb} /{ }^{238} \mathrm{U} 601.7 \pm 1.3 \mathrm{Ma}\right)$ and interspersed with unknown analyses at a 1:4 ratio for elemental and depth-dependent fractionation. Data reduction was performed using the IgorPro (Paton et al., 2010) based Iolite 3.4 software with Visual Age data reduction scheme (Petrus and Kamber, 2012). A Stacey and Kramer (1975) common Pb correction was applied in Tera-Wasserburg concordia space using IsoPlot R software (Vermeesch, 2018). While showing an inherited component of Cambrian $(\sim 15 \%)$ and Miocene $(<10 \%)$ zircons.

\section{Results}

\subsection{Petrography and mineralogy of ash fall tuffs}

Tuffs from the Pliocene-Pleistocene Humahuaca and Casa Grande basins, investigated for this study, are characterized for vitro-clastic textures, showing bubble-wall glass shards with cuspate or tubular shapes ( 0.1 to $1 \mathrm{~mm}$ in diameter) and scarce pumice shards (1.4 to $0.7 \mathrm{~mm}$ in diameter), immersed into a fine vitreous mesostasis. In the Uquía and Mal Paso Formations, the vitreous tuffs are rich in phenocrysts (5-25\% crystals) largely devoid of lithics $(<2 \%)$. Phenocrysts generally are angular and consist of andesine to oligo-andesine, quartz, brown biotite and green hornblende and as accessories magnetite, zircon and minor titanite.

The young group of tuffs, interspersed in alluvial fans, sheet flood deposits, are vitreous (1-5\% crystals) and some of them rich in phenocrysts $(20-25 \%$ 
crystals). Phenocrysts are angular to subangular and consist of andesine to calcic andesine, quartz, biotite, and hornblende. A distinct and distinguishing feature is the presence of clinopyroxene-orthopyroxene, mainly as accessory phase, as well as magnetite, zircon and minor titanite.

\subsection{Characteristics of the ash fall tuff deposits and associated clastic facies}

The studied ash fall deposits display a homogenous internal texture or normally graded stratification, in some cases laminated, exhibit flat to irregular bases, in cases filling alluvial channels and use to show signs of reworking on tops or they are covered by post-eruptive reworked previously lithified ash layers They have variable thickness 0.10 to $1.5 \mathrm{~m}$ and use to be tabular or lenticular (Fig. 4 and Table 1).

Ash-fall tuffs are intercalated into matrix to clast-supported massive conglomerates with sandy and muddy matrix, in cases imbricated associated to medium-to very coarse-grained sandstones which correspond to alluvial fan deposits dominated by debris flow and deep sandy gravel braided, as is observed in Casa Grande, Incahuasi, Quitiacara and Molino profiles. In other cases as in Alonso and San Roque sections they are interspersed between medium to coarse-grained sandstones; moderately to well-sorted and laminated to massive mudstones and siltstones which correspond to floodplain and shallow ephemeral lake deposits (Fig. 5).

\subsection{Geochemical characterization}

Major and trace element geochemical analyses were performed on whole-rock of dated ash-fall tuffs samples from the studied stratigraphic sections in the Pliocene-Pleistocene deposits (Fig. 3) in order to constrain their sources and evaluate them as potential geochemical tracers to stablish stratigraphic correlations. Results of whole-rock and trace elements analyses are listed in table $2 \mathrm{~A}$ and 2B. As some samples show high loss of ignition (LOI) values, only immobile elements were chosen for their characterization and interpretation. For the classification of the tuffs we used $\mathrm{Zr}$ / $\mathrm{TiO}_{2}$ versus $\mathrm{Nb} / \mathrm{Y}$ diagram (Fig. 6) (Winchester and Floyd, 1977). The tuff samples mainly plot in the rhyodacite-dacite field with some scattered in the andesite and trachy-andesite fields.
Compositionally, they are peraluminous bordering metaluminous (A/CNK=1.05-1.39). The Uquía and Mal Paso Formations tuffs (old group tuffs) show a homogeneous and distinct composition. They are characterized by $58-70 \%$ anhydrous $\mathrm{SiO}_{2}$, 2.2-3.5\% $\mathrm{Na}_{2} \mathrm{O}$ and $1.0-4.8 \% \mathrm{~K}_{2} \mathrm{O}$ contents. With $\mathrm{FeO} / \mathrm{MgO}(1.0-1.8)$ they are in the calc-alkaline range (Miyashiro, 1974) and show $\mathrm{TiO}_{2}$ contents of $0.2-0.6 \%$. The young group of tuffs, intercalated in Pleistocene alluvial fans sheet flood deposits, also form a compositional coherent group. They have $61-69 \%$ anhydrous $\mathrm{SiO}_{2}, 2.2-3.1 \% \mathrm{Na}_{2} \mathrm{O}$ and $1.5-3.0 \% \mathrm{~K}_{2} \mathrm{O}$ contents. Their $\mathrm{FeO} / \mathrm{MgO}(1.8-2.8)$ puts them in the calc-alkaline range Miyashiro (1974) with a $\mathrm{TiO}_{2}$ contents are $0.3-0.7 \%$.

The major difference between the two groups lies in their trace elements contents. The young group of tuffs is distinguished from the old group by its highest ratios $(\mathrm{Sm} / \mathrm{Yb}=2.3-4.2$ versus $2.1-3.2$; $\mathrm{La} / \mathrm{Yb}=9-19$ versus $15-24$ and $\mathrm{La} / \mathrm{Ta}$ ratios $=22-44$ versus $12-32$ (Fig. 7). Moreover the old group shows a major enrichment in $\mathrm{LIL}, \mathrm{Th}, \mathrm{U}$, and $\mathrm{Pb}$, more pronounced $\mathrm{P}$ and Ti negative anomalies and higher $\mathrm{Nb}$ and Ta peaks than the young group (Fig. 8).

\section{4. ${ }^{40} \mathrm{Ar} /{ }^{39} \mathrm{Ar}$ and $\mathrm{U}-\mathrm{Pb}$ zircon ages}

Result of ${ }^{40} \mathrm{Ar} /{ }^{39} \mathrm{Ar}$ dating of sample SR13 $\mathrm{b}$ is summarized in table $3 \mathrm{~A}$ (Appendix Table S1). The age spectrum of this sample provides a plateau age (Fig. 9A) with three or more consecutive gas fractions that represent at least $50 \%$ of the total gas release and are within two standard deviations of each other (Mean Square Weighted Deviation less than 2.5). Based on the isochron regression to initial ${ }^{40} \mathrm{Ar} /{ }^{36} \mathrm{Ar}$ there is no evidence this sample had any significant inherited ${ }^{40} \mathrm{Ar}$ (Fig. 9B). The integrated age $(2,563 \pm 28 \mathrm{ka})$ is within error of the plateau age $(2,556 \pm 26 \mathrm{ka})$ (Fig. 9A) and the isochron age $(2,558 \pm 52 \mathrm{ka})$. We prefer the plateau age of $2,556 \pm 26 \mathrm{ka}$ because of the higher precision over the isochron age. In table 3A (Appendix Table S1) are listed ages quoted to the \pm 1 sigma level and calculated using the constants of Renne et al. (2010).

Laser Ablation Inductively Coupled Plasma Mass Spectrometry (LA-ICP-MS) U-Pb dating of zircon from sample MN2, from the Alonso profile, mainly yielded young concordant zircons with a ${ }^{206} \mathrm{~Pb} /{ }^{238} \mathrm{U}$ age of $2.08 \pm 0.04 \mathrm{Ma}(\mathrm{MSWD}=2.2$ ) (Fig. 10, Appendix: Table S2). 


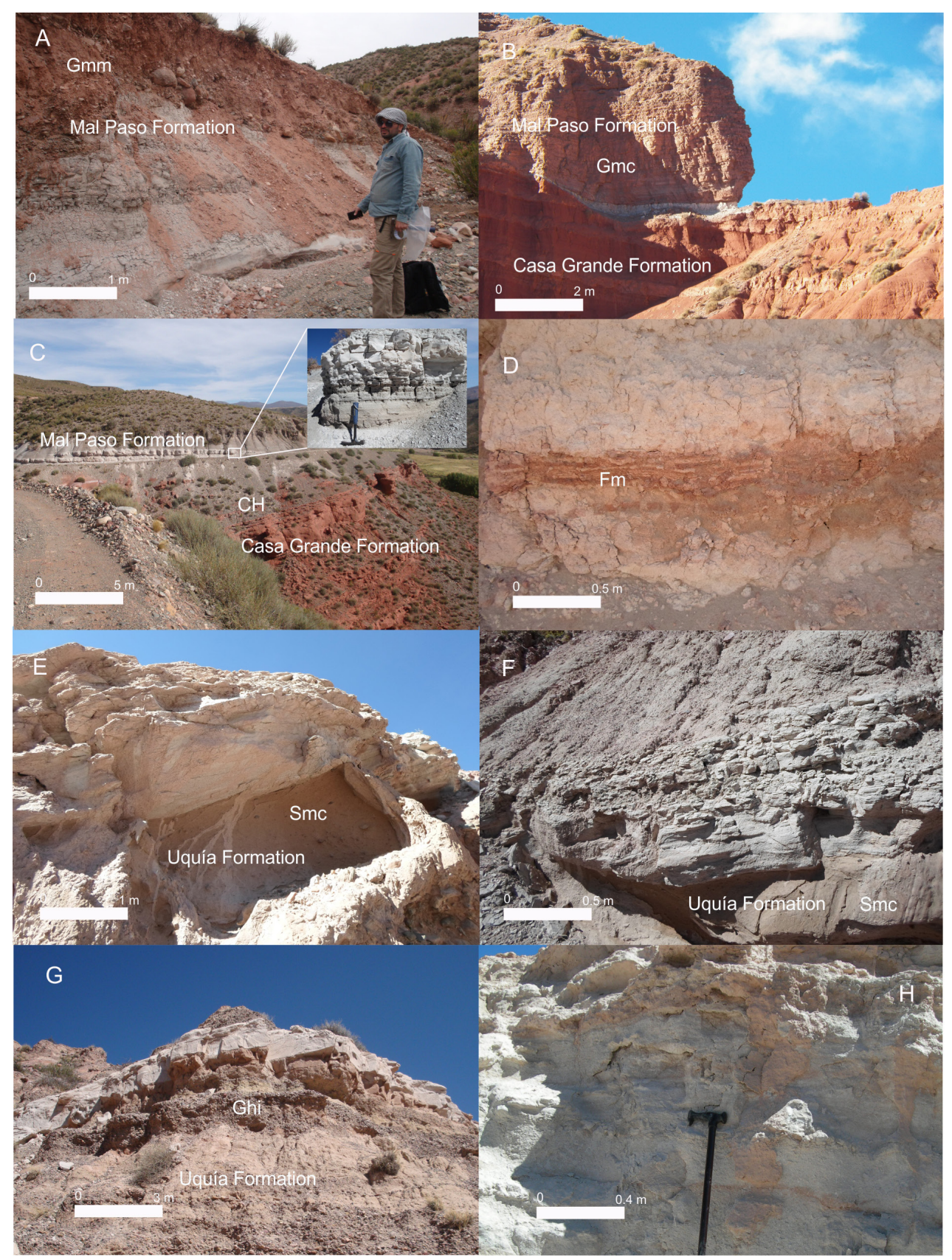

FIG. 4. A. Basal level of the normal graded stratified tuff in the southern part of the Casa Grande basin (Quebrada De Salida), Gmm facies (matrix-supported, massive conglomerate with a solid sandy and muddy matrix. Plastic debris flow). B. Massive tuff filling channel in Casa Grande river profile (3.74 $\pm 0.04 \mathrm{Ma})$, Gmc facies pseudoplastic debris flow. C. Tuff level in the center of Casa Grande basin (2.95 $\pm 0.02 \mathrm{Ma})$. CH channel. In the inset, detail showing a massive tuff on top of a laminated reworked tuff. D. Massive level of tuff in Alonso profile, irregular basal contact with fine-grained deposits accumulated in the floodplain (Fm. Facies: massive multi-coloured kaolinic clays with mud-cracks beds) later modified by desiccation. E. Tuff in Incahuasi south profile with flat base on top of Smc facies(medium- to very coarse-grained sandstones; moderately- to well-sorted; massive) F. Normal graded stratified level of tuff, laminated to the roof overlying Smc facies gravity flow deposits of high flatbed regime and single dynamic events such as flash floods. Incahuasi south profile. G. Massive tuff level in the Quitiacara profile with flat base and roof. Ghi facies (fining-upward clast-supported conglomerate with a sandy matrix and imbricated clasts), high energy deposits, longitudinal bars. H. Alternating lapilli and ash levels with irregular contacts. San Roque profile. 


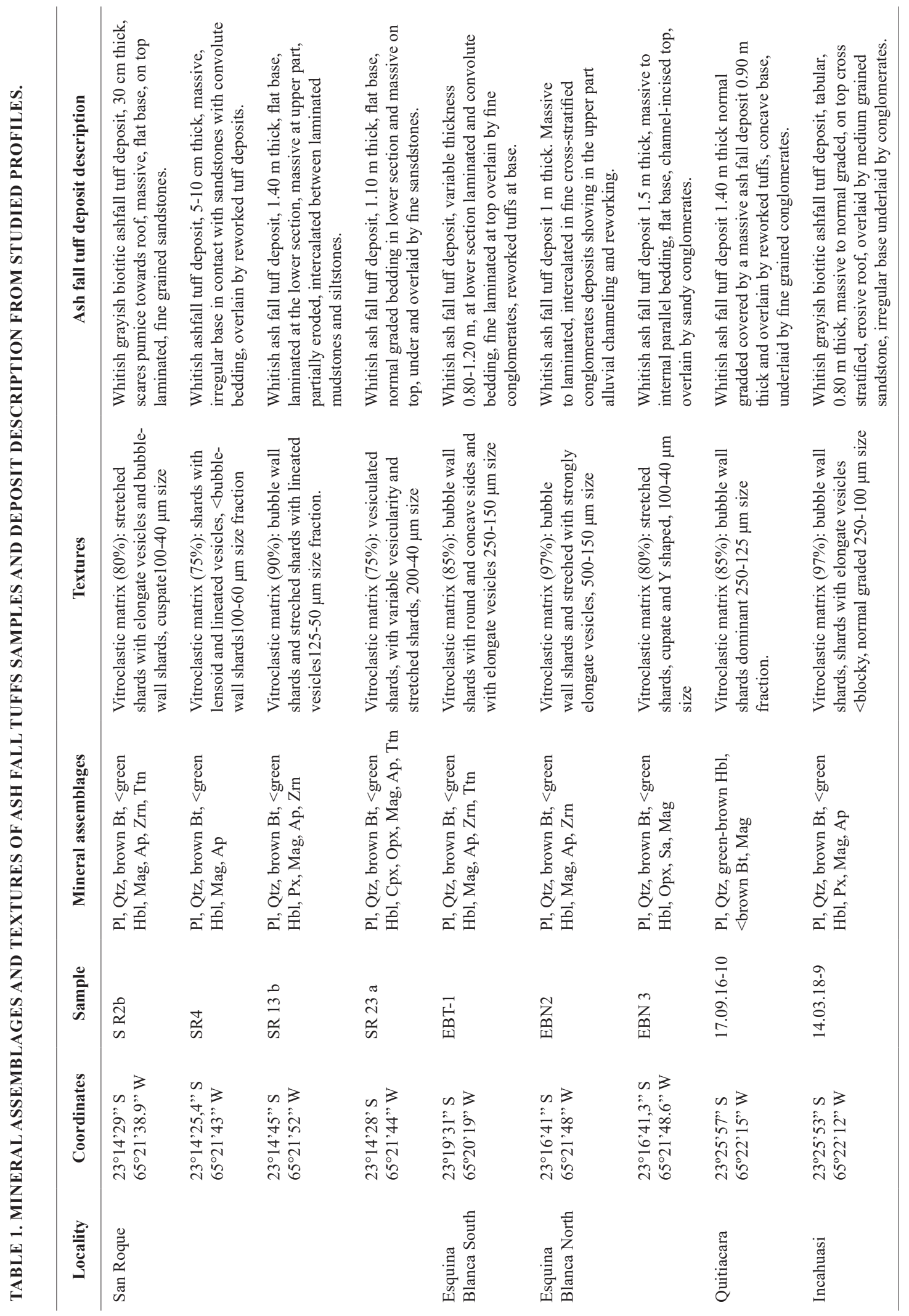




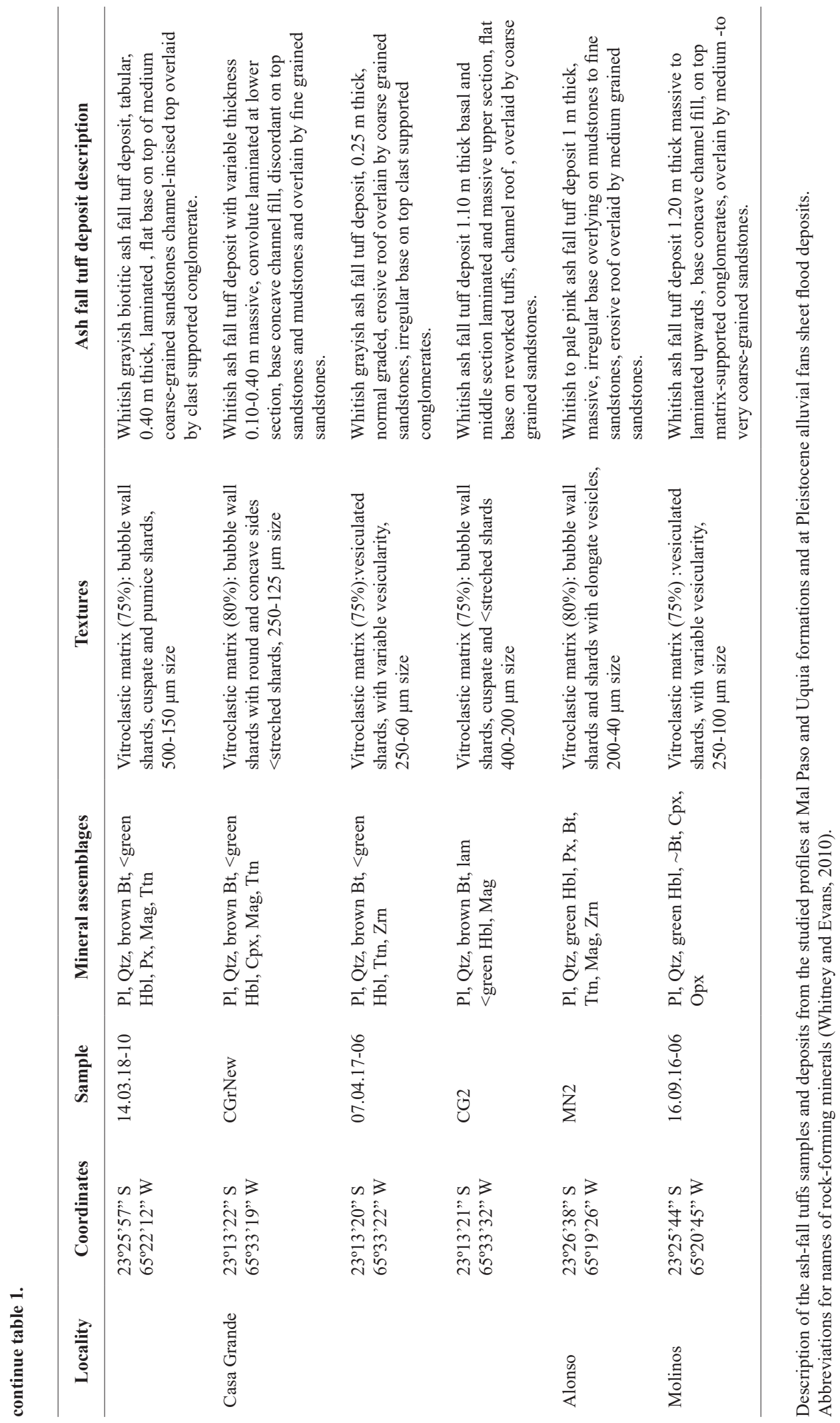




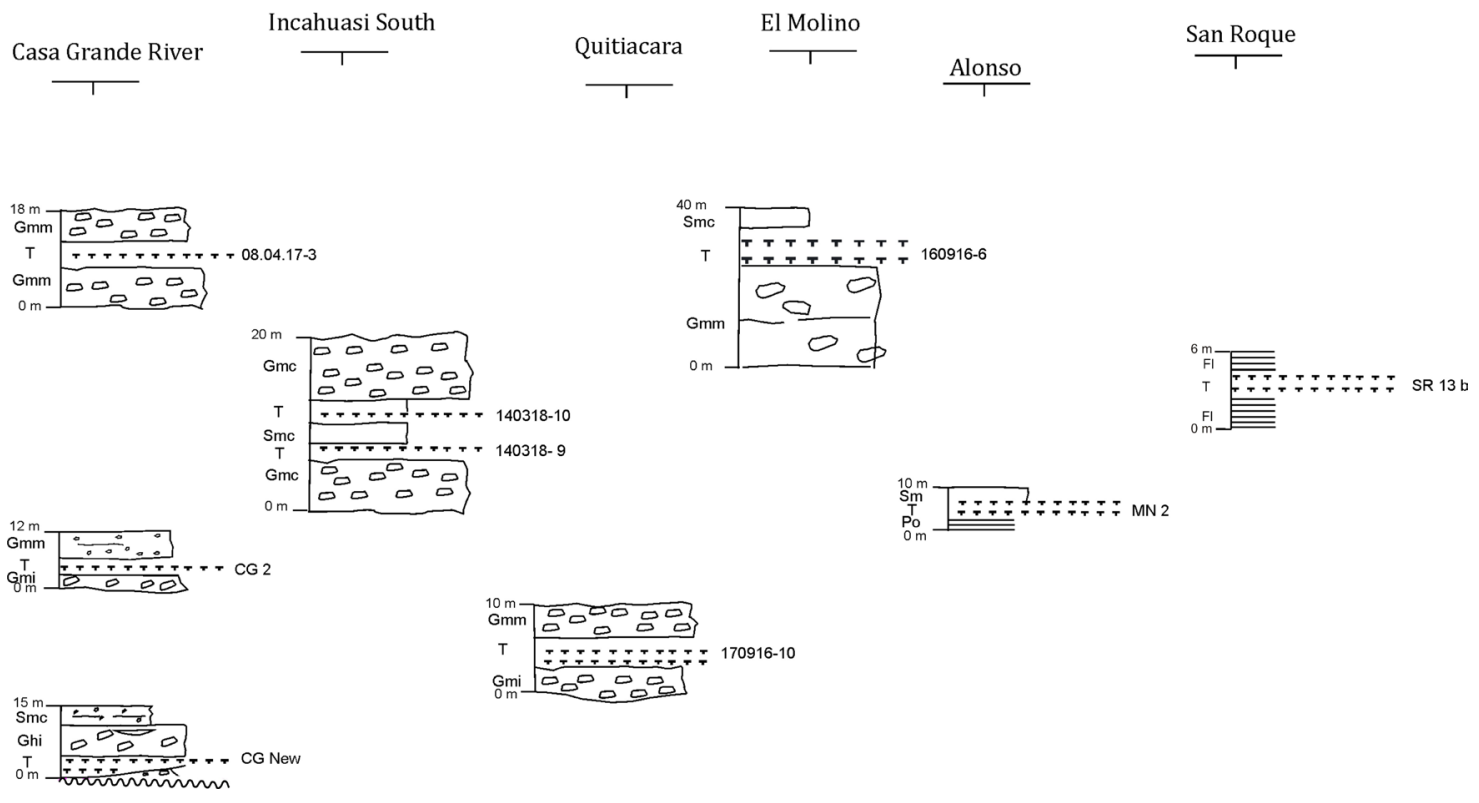

FIG. 5. Enlarged partial sections of stratigraphic columns from figure 3 showing detail of ash-fall tuffs and host sediments. T (ash-fall tuff), Fl (clayey siltstone laminated), Gmm (matrix-supported, massive conglomerate with a solid sandy and muddy matrix), Gmi (clast-supported conglomerate with imbrication ), Gmc (clast-supported conglomerate, massive), Ghi (fining-upward clastsupported conglomerate with a sandy matrix and imbricated clasts), Po (mudstones to very fine-grained sandstones; massive). The code to the right of the tuff level indicates the sample number.

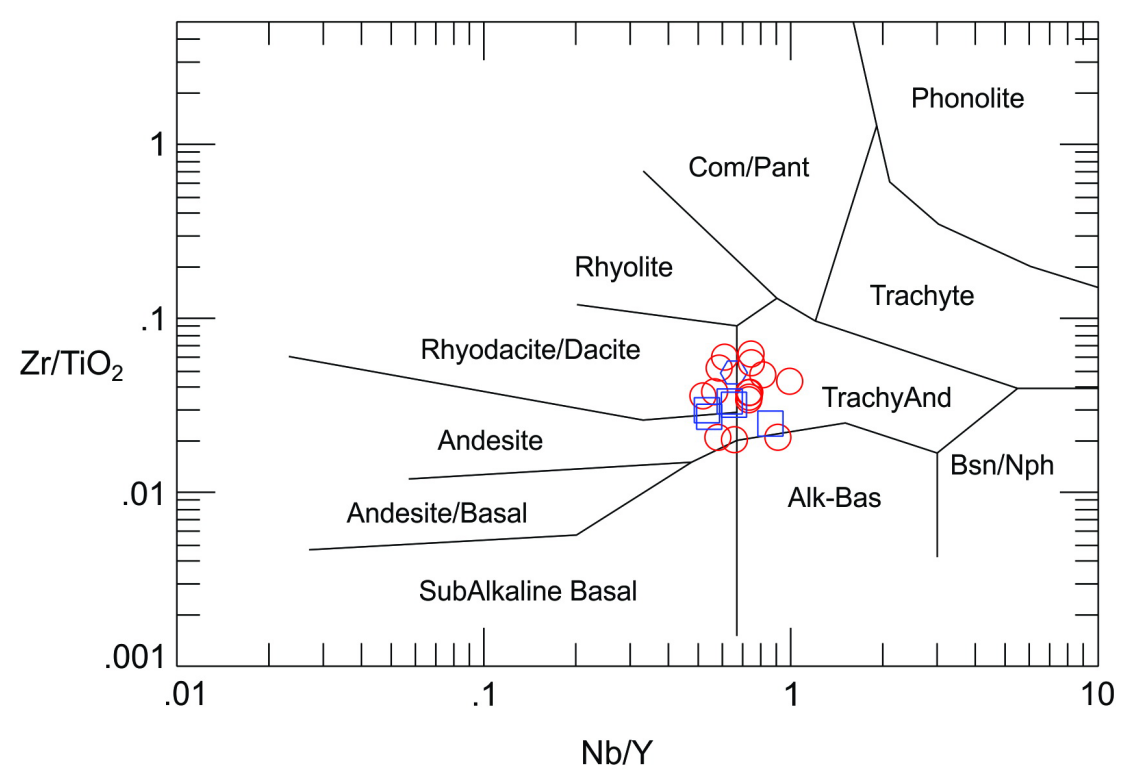

FIG. 6. Plot of $\mathrm{Zr} / \mathrm{TiO}_{2}$ versus $\mathrm{Nb} / \mathrm{Y}$ from Winchester and Floyd (1977) for whole rock analyses (Table 2A, B) of tuff samples from the Uquía and Mal Paso formations (red circles) and from Pleistocene alluvial fans sheet flood deposits (blue squares). 
TABLE 2A. REPRESENTATIVE MAJOR AND TRACE ELEMENT ANALYSES FOR UQUIA AND MAL PASO FORMATIONS TUFFS

\begin{tabular}{|c|c|c|c|c|c|c|c|c|c|c|c|}
\hline & Esquina & Blanca & Sur & Esquina & Blanca & Norte & & San & Roque & & Quitiacara \\
\hline Sample & EsqBI-1 & EB 911 & ESBT1 & EBN2 & EBN-2, & EBN-3 & SR-2b & SR-4 & SR-23a & SR-13B & 17091610 \\
\hline $\mathrm{SiO}_{2}$ & 69.23 & 66.7 & 65.21 & 63.57 & 65.6 & 63.45 & 64.81 & 70.04 & 65.28 & 63.54 & 71.07 \\
\hline $\mathrm{TiO}_{2}$ & 0.53 & 0.34 & 0.53 & 0.321 & 0.36 & 0.35 & 0.59 & 0.28 & 0.50 & 0.29 & 0.27 \\
\hline $\mathbf{A}_{12} \mathbf{O}_{3}$ & 14.57 & 14.99 & 16.76 & 16.34 & 16.85 & 16.53 & 16.6 & 14.59 & 15.51 & 12.34 & 12.41 \\
\hline $\mathrm{Fe}_{2} \mathrm{O}_{3}$ & 2.87 & 1.83 & 2.84 & 2.34 & 2.17 & 2.41 & 3.73 & 1.8 & 3.92 & 1.58 & 1.66 \\
\hline MnO & 0.06 & 0.07 & 0.07 & 0.07 & 0.06 & 0.06 & 0.04 & 0.06 & 0.05 & 0.07 & 0.07 \\
\hline MgO & 1.33 & 2.85 & 1.85 & 2.5 & 2.17 & 2.63 & 2.22 & 0.93 & 2.01 & 1.37 & 1.05 \\
\hline $\mathrm{CaO}$ & 3.16 & 2.38 & 3.68 & 1.88 & 3.09 & 2.77 & 2.44 & 1.37 & 2.01 & 6.79 & 1.75 \\
\hline $\mathrm{Na}_{2} \mathrm{O}$ & 2.94 & 2.15 & 3 & 2.95 & 2.66 & 2.75 & 2.24 & 2.34 & 2.48 & 2.61 & 2.91 \\
\hline $\mathbf{K}_{2} \mathbf{O}$ & 2.79 & 2.12 & 2.06 & 3.6 & 2.23 & 2.45 & 3.66 & 5.6 & 3.89 & 4.15 & 4.79 \\
\hline $\mathbf{P}_{2} \mathbf{O}_{5}$ & 0.116 & 0.08 & 0.109 & 0.017 & 0.087 & 0.11 & 0.219 & 0.139 & 0.123 & 0.11 & 0.03 \\
\hline LOI & 2.89 & 5.42 & 3.34 & 6.86 & 4.51 & 7.74 & 3.63 & 3.54 & 3.86 & 7.39 & 3.72 \\
\hline Total & 100.63 & 98.94 & 99.5 & 100.44 & 99.59 & 101.16 & 99.99 & 100.64 & 99.7 & 100.25 & 99.71 \\
\hline $\mathbf{B a}$ & 498 & 360 & 486 & 439 & 490 & 576 & 552 & 597 & 637 & 696 & 626 \\
\hline $\mathbf{R b}$ & 111 & 112 & 97 & 113 & 100 & 101 & 180 & 271 & 154 & 144 & 191 \\
\hline $\mathrm{Sr}$ & 314 & 325 & 396 & 226 & 384 & 325 & 318 & 209 & 277 & 279 & 223 \\
\hline Cs & - & 6.79 & 6.9 & 10 & 10.8 & 7.4 & 24.5 & 27.2 & 17.7 & - & 13.6 \\
\hline $\mathbf{N b}$ & 13 & 21 & 14 & 13 & 15 & 13 & 14 & 14 & 13 & 12 & 19 \\
\hline Hf & 7 & 6 & 6.1 & 9 & 4.4 & 5.1 & 7.1 & 3.7 & 5.2 & 4 & 4 \\
\hline $\mathbf{Z r}$ & 230 & 211 & 205 & 290 & 156 & 170 & 205 & 118 & 163 & 165 & 127 \\
\hline $\mathbf{Y}$ & 13 & 28 & 19 & 25 & 19 & 20 & 19 & 10 & 20 & 16 & 28 \\
\hline Ta & 1.24 & 1.58 & 1.38 & 0.94 & 1.83 & 1.12 & 1.63 & 1.63 & 1.17 & - & 1.5 \\
\hline Th & 15.4 & 31 & 19 & 17 & 18.7 & 14.1 & 19.9 & 25.1 & 14.8 & 15 & 16 \\
\hline $\mathbf{U}$ & 3.8 & 5 & 3.4 & 5 & 5.6 & 3.5 & 7.5 & 15.1 & 4.6 & 4 & 8 \\
\hline $\mathbf{N i}$ & 5 & 4 & 1 & 4 & 6 & 50 & 11 & 7 & 12 & 1 & 4 \\
\hline Co & 11 & 4 & 54 & 13 & 12 & 4 & 12 & 10 & 10 & 4 & 4 \\
\hline $\mathrm{Cr}$ & 17 & 6.93 & 16 & 23 & 14 & 15 & 32 & 10 & 35 & 18 & 26.4 \\
\hline Sc & 6.7 & 4.65 & 6.2 & - & 5.7 & 6.3 & 8.2 & 3.5 & 8.6 & - & 5.2 \\
\hline $\mathbf{P b}$ & - & 19 & - & 23.4 & - & - & - & - & - & - & 30.99 \\
\hline La & 36.1 & 41.5 & 37.8 & 30.9 & 32.2 & 33.9 & 40 & 29.7 & 36.1 & - & 29.2 \\
\hline $\mathrm{Ce}$ & 75.5 & 82.9 & 81.3 & 67.5 & 77 & 81.2 & 82.1 & 56.9 & 80.6 & - & 60.08 \\
\hline Nd & 29.6 & 29.7 & 29.9 & 22 & 26.4 & 32 & 32.8 & 18.8 & 32.1 & - & 27 \\
\hline Sm & 5.5 & 5.29 & 5.51 & 3.87 & 5.33 & 6.04 & 6.52 & 3.88 & 6.33 & - & 5.3 \\
\hline $\mathbf{E u}$ & 1.11 & 0.92 & 1.1 & 1.02 & 0.98 & 0.92 & 1.1 & 0.48 & 1.11 & - & 0.8 \\
\hline Gd & - & 4.58 & - & - & - & - & - & - & - & - & 4.9 \\
\hline $\mathbf{T b}$ & 0.457 & 0.7 & 0.584 & 0.49 & 0.522 & 0.577 & 0.698 & 0.141 & 0.669 & - & 0.7 \\
\hline Dy & - & 4.1 & - & - & - & - & - & - & - & - & 4.3 \\
\hline Ho & - & 0.84 & - & - & - & - & - & - & - & - & 0.9 \\
\hline $\mathbf{E r}$ & - & 2.32 & - & - & - & - & - & - & - & - & 2.4 \\
\hline $\mathbf{T m}$ & - & 0.33 & - & - & - & - & - & - & - & - & 0.3 \\
\hline $\mathbf{Y b}$ & 1.72 & 2.18 & 1.92 & 1.74 & 2.07 & 1.98 & 1.99 & 1.03 & 2.09 & - & 2.5 \\
\hline Lu & 0.247 & 0.35 & 0.27 & 0.27 & 0.293 & 0.278 & 0.272 & 0.197 & 0.298 & - & 0.3 \\
\hline A/CNK & 1.05 & 1.48 & 1.2 & 1.34 & 1.39 & 1.37 & 1.41 & 1.18 & 1.29 & 0.586 & 0.945 \\
\hline
\end{tabular}


TABLE 2B. REPRESENTATIVE MAJOR AND TRACE ELEMENT ANALYSES FOR UQUIA AND MAL PASO FORMATIONS TUFFS AND PLEISTOCENE TUFFS

\begin{tabular}{|c|c|c|c|c|c|c|c|c|c|}
\hline \multirow[b]{2}{*}{ Sample } & \multirow{2}{*}{$\begin{array}{c}\text { Casa } \\
7041706\end{array}$} & \multirow{2}{*}{$\begin{array}{c}\text { Grande } \\
\text { CGrNew }\end{array}$} & \multicolumn{2}{|c|}{ Incahuasi } & \multirow{2}{*}{$\begin{array}{c}\text { CGrande } \\
* \text { CG2 a }\end{array}$} & \multirow{2}{*}{$\begin{array}{l}\text { Incahuasi } \\
* 19071405\end{array}$} & \multicolumn{2}{|c|}{ Molinos } & \multirow{2}{*}{$\begin{array}{l}\text { Alonso } \\
* \text { MN2 }\end{array}$} \\
\hline & & & 143189 & 1431810 & & & *16091606 & *16091600 & \\
\hline $\mathrm{SiO}_{2}$ & 57.6 & 60.5 & 66.0 & 63.05 & 72.05 & 65.3 & 68.52 & 67.16 & 61.36 \\
\hline $\mathrm{TiO}_{2}$ & 0.54 & 0.56 & 0.33 & 0.517 & 0.62 & 0.46 & 0.74 & 0.67 & 0.64 \\
\hline $\mathrm{Al}_{2} \mathrm{O}_{3}$ & 18.8 & 18.4 & 14.49 & 15.62 & 13.92 & 15.2 & 11.96 & 14.61 & 16.04 \\
\hline $\mathrm{Fe}_{2} \mathrm{O}_{3}$ & 3.48 & 3.61 & 2.06 & 3.09 & 2.19 & 2.69 & 4.03 & 3.72 & 3.79 \\
\hline MnO & 0.09 & 0.08 & 0.07 & 0.11 & 0.03 & 0.03 & 0.09 & 0.08 & 0.04 \\
\hline MgO & 3.88 & 3.38 & 1.49 & 1.9 & 1.14 & 2.17 & 1.51 & 2.03 & 1.69 \\
\hline $\mathrm{CaO}$ & 4.95 & 3.88 & 2.79 & 3.69 & 2.28 & 2.9 & 3.21 & 3.86 & 2.65 \\
\hline $\mathrm{Na}_{2} \mathrm{O}$ & 2.97 & 3.41 & 2.73 & 3.03 & 2.24 & 2.91 & 3.13 & 3.09 & 2.16 \\
\hline $\mathbf{K}_{2} \mathbf{O}$ & 0.98 & 1.62 & 3.64 & 2.91 & 2.48 & 3.03 & 2.97 & 1.74 & 2.71 \\
\hline $\mathbf{P}_{2} \mathbf{O}_{5}$ & 0.13 & 0.13 & 0.10 & 0.09 & 0.04 & 0.13 & 0.16 & 0.09 & 0.10 \\
\hline LOI & 6.3 & 4.2 & 6.54 & 5.72 & 2.2 & 4.7 & 4.4 & 2.561 & 8.95 \\
\hline Total & 99.72 & 99.77 & 100.22 & 99.74 & 99.18 & 99.52 & 100.7 & 99.65 & 100.13 \\
\hline $\mathrm{Ba}$ & 800 & 500 & 485 & 666 & 601 & 500 & 458 & 456 & 451 \\
\hline $\mathbf{R b}$ & 46.3 & 70.8 & 213 & 175 & 117 & 120.1 & 114 & 80 & 154 \\
\hline $\mathrm{Sr}$ & 450 & 350 & 337 & 406 & 348 & 310 & 253 & 426 & 354 \\
\hline Cs & 8 & 9.9 & 18.05 & 16.2 & 18 & 9.8 & 8.3 & 6.6 & 14.9 \\
\hline $\mathbf{N b}$ & 19.22 & 18.44 & 17 & 13 & 15 & 18.71 & 13 & 12 & 15 \\
\hline Hf & 2.33 & 2.26 & 6 & 6 & 6 & 2.32 & 5 & 6 & 5 \\
\hline $\mathrm{Zr}$ & 56.4 & 58.4 & 198 & 198 & 220 & 58 & 195 & 225 & 203 \\
\hline $\mathbf{Y}$ & 21.2 & 20 & 28 & 23 & 19 & 21.8 & 24 & 19 & 23 \\
\hline Ta & 1.8 & 1.7 & 2.05 & 1.43 & 1.05 & 1.7 & 1.1 & 0.9 & 0.95 \\
\hline Th & 17.6 & 19 & 26 & 20 & 11 & 20.1 & 15 & 14 & 17 \\
\hline $\mathbf{U}$ & 0.7 & 1.7 & 8 & 3 & 3 & 3.9 & 5 & 4 & 3 \\
\hline $\mathbf{N i}$ & 4.4 & 3.3 & 5 & 3 & 8.28 & 2.9 & 7 & 1 & 34 \\
\hline Co & 14.4 & 6.8 & 4 & 8 & 6.16 & 12.9 & 15 & 9 & 1 \\
\hline $\mathrm{Cr}$ & 6 & 7 & 76 & 78 & 20.2 & 7 & 56 & 76 & 73 \\
\hline Sc & 8 & 8.2 & 6.1 & 7.2 & 5.95 & 8.4 & 8.3 & 6.1 & 10.2 \\
\hline $\mathbf{P b}$ & 24.73 & 27.52 & 31.4 & 25.1 & 19.3 & 23.95 & 16.87 & 20.45 & 26.3 \\
\hline $\mathbf{L a}$ & 25.4 & 29.8 & 32.4 & 39.2 & 45.7 & 39.2 & 26.8 & 35.5 & 32.8 \\
\hline $\mathrm{Ce}$ & 68.92 & 71.88 & 67.4 & 78.1 & 80.2 & 75.34 & 57.15 & 68.58 & 68.8 \\
\hline Nd & 29 & 26.4 & 30.9 & 29.7 & 31 & 32.6 & 26.7 & 29.4 & 31.8 \\
\hline Sm & 6 & 5.5 & 6.36 & 5.62 & 5.27 & 5.6 & 5.9 & 5 & 5.7 \\
\hline Eu & 1.2 & 1.1 & 0.84 & 1.24 & 1.33 & 1.1 & 1 & 1.1 & 1.2 \\
\hline Gd & 5.5 & 4.6 & 5.27 & 4.57 & 4.35 & 5.4 & 5 & 3.8 & 3.98 \\
\hline $\mathbf{T b}$ & 0.7 & 0.6 & 0.815 & 0.679 & 0.61 & 0.6 & 0.6 & 0.4 & 0.52 \\
\hline Dy & 5.1 & 4.5 & 4.77 & 3.75 & 3.14 & 4.6 & 4.4 & 2.7 & 2.84 \\
\hline Ho & 0.9 & 0.8 & 0.893 & 0.729 & 0.61 & 0.9 & 0.7 & 0.6 & 0.509 \\
\hline $\mathbf{E r}$ & 2.5 & 2.3 & 2.56 & 2.11 & 1.58 & 2.5 & 2.2 & 1.2 & 1.44 \\
\hline $\mathbf{T m}$ & 0.4 & 0.3 & 0.35 & 0.279 & 0.22 & 0.3 & 0.3 & 0.2 & 0.194 \\
\hline $\mathbf{Y b}$ & 2.7 & 2.2 & 2.46 & 1.92 & 1.49 & 2.4 & 2.2 & 1.2 & 1.365 \\
\hline Lu & 0.4 & 0.3 & 0.371 & 0.259 & 0.23 & 0.4 & 0.3 & 0.2 & 0.187 \\
\hline A/CNK & 1.25 & 1.28 & 1.075 & 1.056 & 1.33 & 1.14 & 0.84 & 1.048 & 1.423 \\
\hline
\end{tabular}



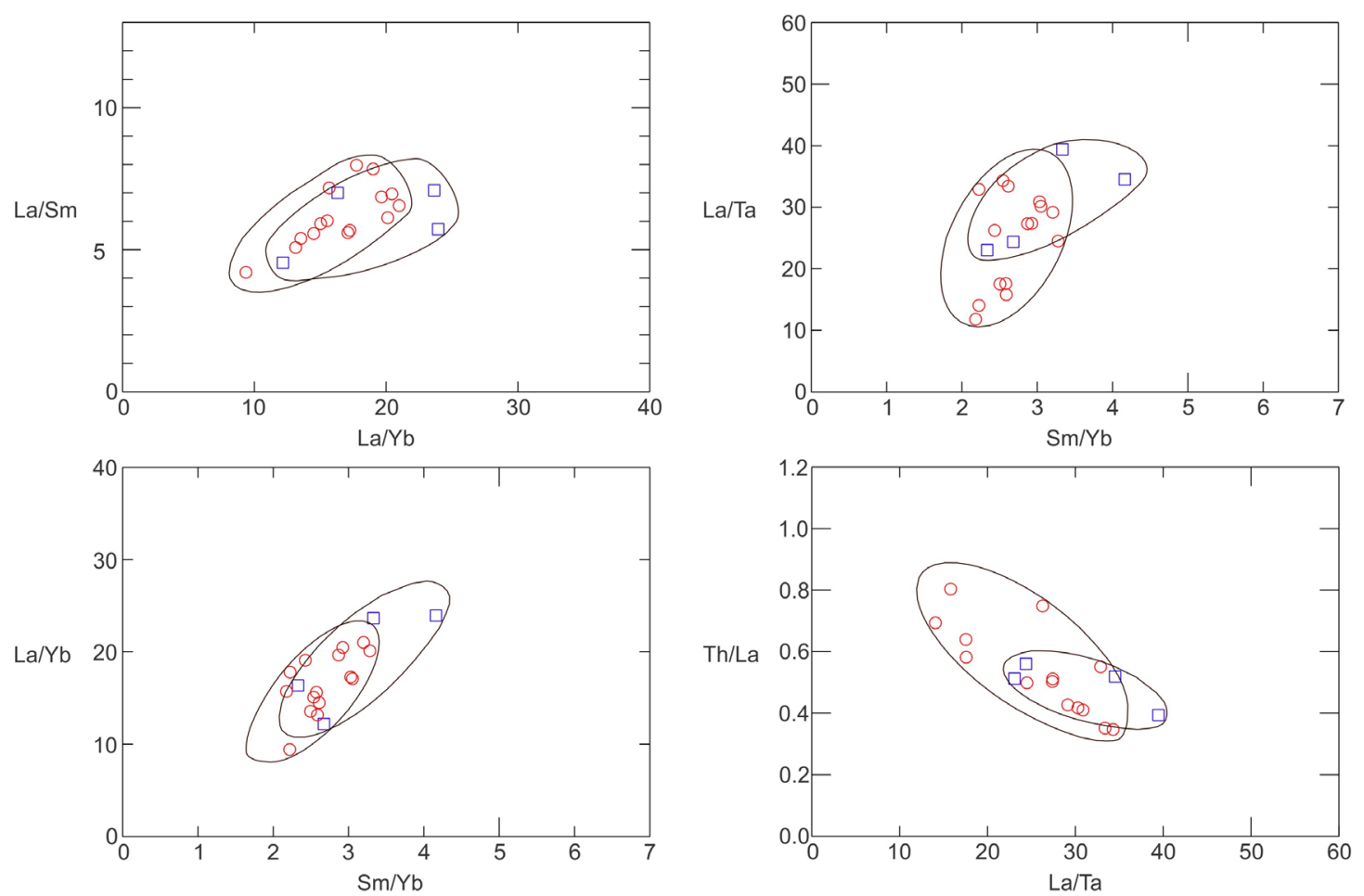

FIG. 7. Trace element plots showing some general chemical features of tuff samples from the Uquía and Mal Paso formations (red circles) and from Pleistocene alluvial fans sheet flood deposits (blue squares). Data from the table 2A and B.

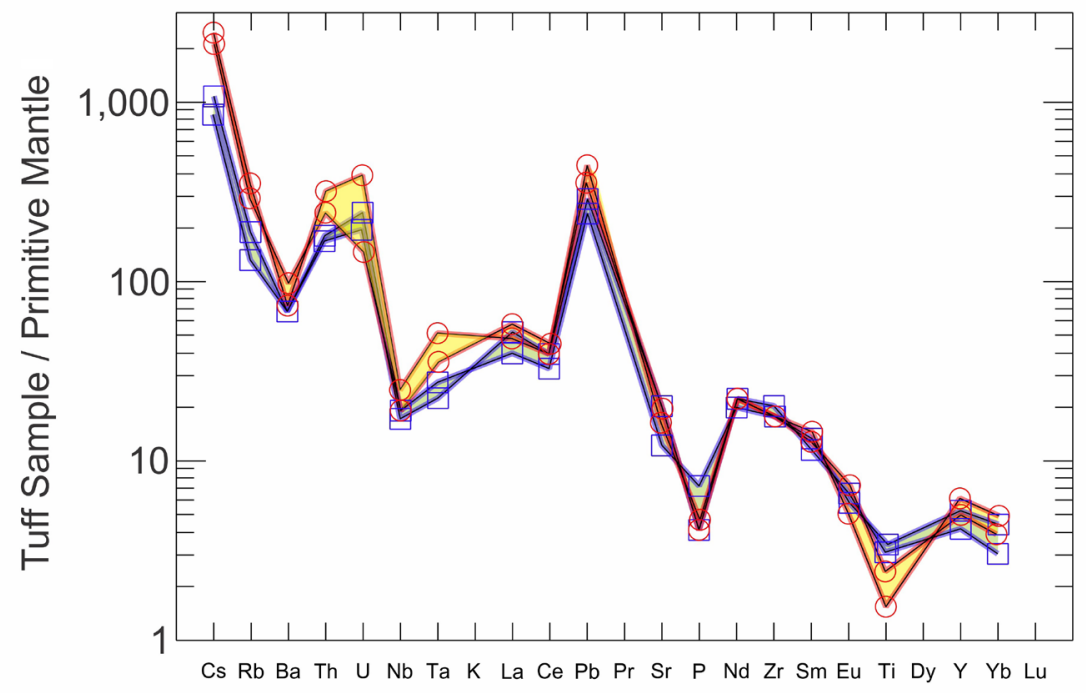

FIG. 8. Representative trace element patterns of old (red circles) and young group of tuffs. (blue squares). Normalized to primitive mantle concentrations (Sun and McDonough, 1989). 
TABLE 3A. RESULTS OF ${ }^{40} A r{ }^{39}$ Ar DATING OF SAMPLE SR-13B.

\begin{tabular}{|c|c|c|c|c|c|c|}
\hline Sample & Mineral & $\begin{array}{c}\text { Integrated } \\
\text { Age (ka) }\end{array}$ & $\begin{array}{l}\text { Plateau age } \\
\text { Age (ka) }\end{array}$ & $\begin{array}{c}\text { Plateau } \\
\text { information }\end{array}$ & $\begin{array}{l}\text { Isochron } \\
\text { Age (ka) }\end{array}$ & $\begin{array}{l}\text { Isoochron } \\
\text { information }\end{array}$ \\
\hline SR-13B & BI & $2,563 \pm 28$ & $2,550 \pm 26$ & $\begin{array}{c}7 \text { of } 8 \text { fractions } \\
99.2 \%{ }^{39} \mathrm{Ar} \\
\text { release } \\
\text { MSWD }=0.6\end{array}$ & $2,558 \pm 52$ & $\begin{array}{c}7 \text { of } 8 \text { fractions } \\
{ }^{40} \mathrm{Ar} /{ }^{36} \mathrm{Ar}= \\
295.6 \pm 2.9 \\
\text { MSWD }=0.68\end{array}$ \\
\hline
\end{tabular}

TABLE 3B. U-Pb ZIRCON AGES OF SAMPLE MN2.

\begin{tabular}{ccccccccccc}
\hline Sample & Mineral & $\begin{array}{c}{ }^{207} \mathrm{~Pb} /{ }^{235} \mathrm{U} \\
\text { Age Ma }\end{array}$ & $\begin{array}{c}\mathbf{2 \sigma} \\
\text { error }\end{array}$ & $\begin{array}{c}{ }^{206} \mathrm{~Pb} / \mathbf{U}^{238} \\
\text { Age (Ma) }\end{array}$ & $\begin{array}{c}\mathbf{2 \sigma} \\
\text { error }\end{array}$ & $\begin{array}{c}{ }^{207} \mathrm{~Pb} /{ }^{206} \mathbf{P b} \\
\text { Age }(\mathbf{M a})\end{array}$ & $\begin{array}{c}\mathbf{2 \sigma} \\
\text { error }\end{array}$ & $\begin{array}{c}\text { Best age } \\
\text { (Ma) }\end{array}$ & $\begin{array}{c}\mathbf{2 \sigma} \\
\text { error }\end{array}$ & Discordance\% \\
\hline MN2 & zircon & 2.4 & 0.75 & 2.1 & 0.18 & -120 & 500 & 2.1 & 0.2 & 12.5 \\
\hline
\end{tabular}
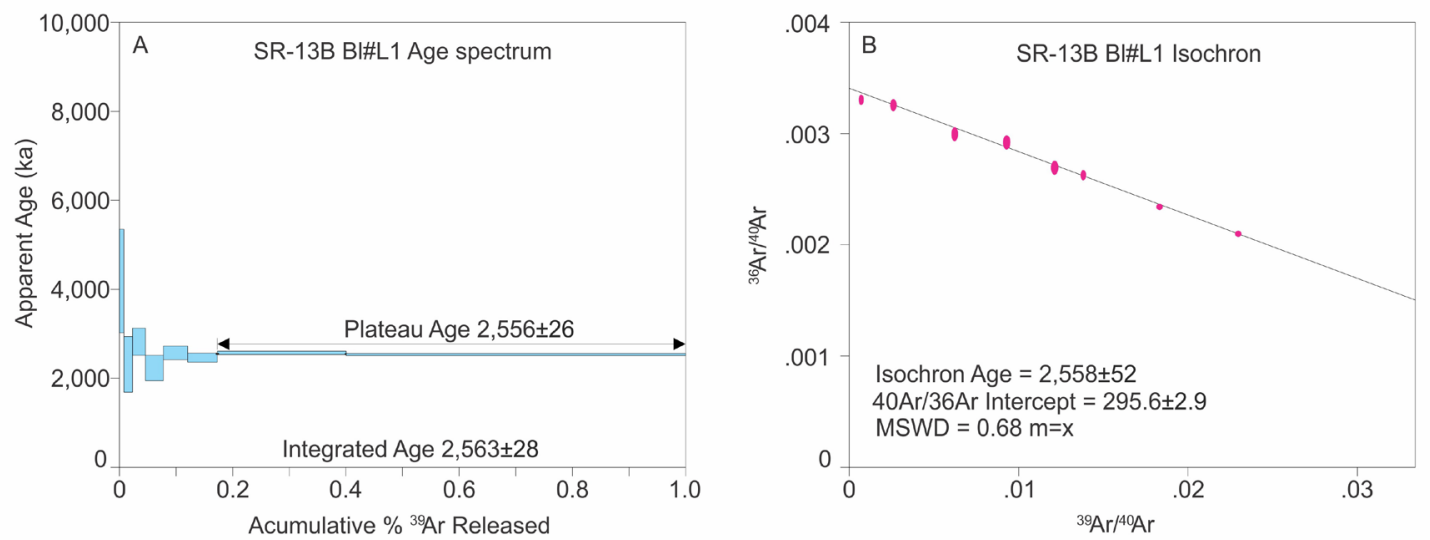

FIG. 9. A. ${ }^{40} \mathrm{Ar} /{ }^{39} \mathrm{Ar}$ age spectrum for SR13b sample. Integrated age $(\mathrm{ka})=2,563 \pm 28$. Plateau age $(\mathrm{ka})=2,550 \pm 26, \mathrm{MSWD}=0.6,99.2 \%$ ${ }^{39} \mathrm{Ar}$ released. B. Isochron for SR13b sample. ${ }^{40} \mathrm{Ar} /{ }^{36} \mathrm{Ar}$ intercept 295.6 $\pm 2.9, \mathrm{MSWD}=0.68$. Isochron age 2,558 $\pm 52 \mathrm{ka}$.

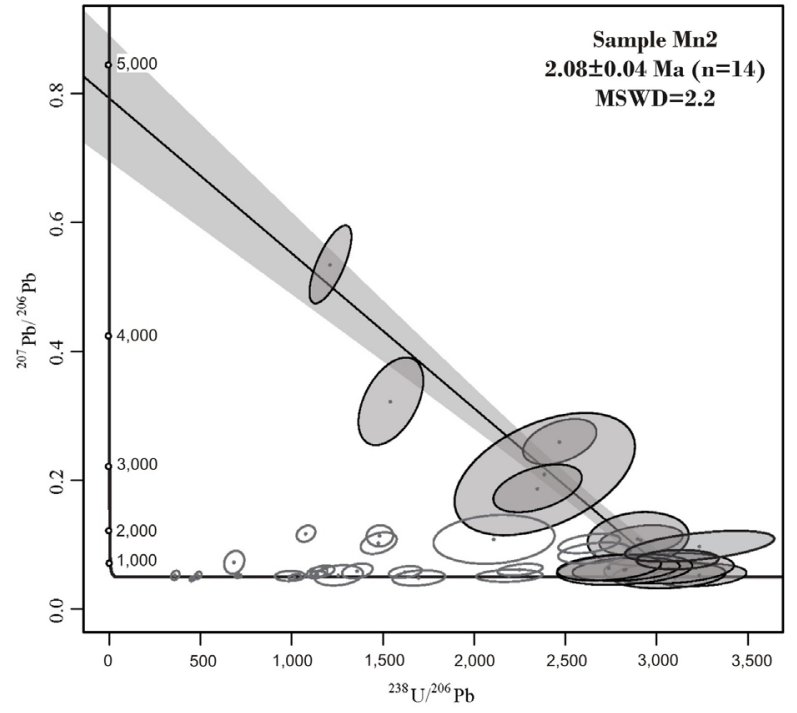

FIG. 10. Tera-Wasserburg diagram for the $\mathrm{U}-\mathrm{Pb}$ data from MN2 sample. Best age $2.08 \pm 0.04 \mathrm{Ma}(\mathrm{n}=14)$ Regressed data are in gray. 


\section{Discussion}

\subsection{Palaeo-environmental conditions during ash deposition}

The geological and paleontological evidences recognized by Reguero et al. (2007), Reguero, and Candela (2008) in their biostratigraphic studies of the Late Neógene deposits of the Quebrada de Humahuaca, suggest that during the Pliocene-Early Pleistocene, the area could have been a wide intermountain valley at 1,400-1,700 m, with a more humid environment than that of the present day and some wet-dry seasonality that permitted the coexistence of forest and open areas, scenario in which the studied ashes would have been deposited.

The sedimentary processes at that time in the Humahuaca and Casa Grande basins were dominated by alluvial fan systems with predominantly debris flow associated with a deep sandy gravel braided fluvial system, floodplains, and shallow ephemeral lacustrine deposition (Galli et al., 2017, 2019). The alluvial fans sheet flood dominated paleoenvironment conditions prevailed throughout the Pleistocene. In these environmental conditions, ash deposition took place covering the relief and being covered by those sedimentary facies, reflection of mass flood activity, which partially limited further erosion (Fig. 5). Although it is frequent to observe evidence of partial erosion and re-deposition by water, especially effective during rainy season. Ash-rich channel fill observe in some cases (Fig. 4b) indicates reworking and deposition during flash floods.

In some sector of the basins, as in San Roque section (Figs. 3, 5), pro-gradation of an alluvial fan into a lacustrine system provided better conditions for the preservation of pyroclastic material, which is interbedded with lacustrine/palustrine fine sandstone and mudstone containing gastropods and diatoms (Galli et al., 2017, 2019).

\subsection{Eruptive pulses and correlations}

Ages of the tuffs from the Pliocene-Pleistocene sequences previously described fall into two distinct clusters, the first includes Uquía and Mal Paso Formations tuffs ranging from 4.3 to $2.6 \mathrm{Ma}$, and the second one giving ages from 2.21 to $0.8 \mathrm{Ma}$, which corresponds to tuffs hosted in alluvial fans, sheet flood deposits. These two age clusters show (Fig. 11) correspondence with the eruptive pulses recognized by de Silva and Gosnold (2007) and with the stages of eruptions identify by Kern et al. (2016) within the Altiplano-Puna Volcanic Complex (APVC) flare-up.

In the lapse of time of the "old eruptive pulse" recognized in the studied region large ignimbrites were erupted to the west and northwest in the Altiplano-Puna Volcanic Complex (APVC,de Silva, 1989a), and to the southwest in southern Puna (Kay and Coira, 2009; Kay et al., 2011). Such is the case of ignimbrites as Puripicar (4.09 Ma), erupted from Chaxas dome complex, Atana (3.96 Ma) and Toconao: 4.0 Ma, from La Pacana caldera, Laguna Amarga (3.8 Ma,) from homonymous caldera, Cueva Negra ( $3.78 \mathrm{Ma}$ ) from Galán caldera, Tara (3.49 Ma) from Guacha caldera, Pastos Grandes (2.89 Ma) from Pastos Grandes caldera (Seggiaro and Hongn, 2000; Lindsay et al., 2001; Kay et al., 2006, 2010; Salisbury et al., 2011) (Figs. 11, 12).

During the lapse of time of the recognized "young eruptive pulse" took place the eruption of the ignimbrites Galán (2.6 Ma), Laguna Colorada (1.98 Ma), Puripica Chico (1.70 Ma), Purico (0.98 Ma) (Kay et al., 2010; Salisbury et al., 2011).

Volume-time relations plot of Altiplano-Puna volcanic complex and southern Puna ignimbrites for the time span of the pulses recognized in Humahuaca and Casa Grande basins (Fig. 11), shows a clear coincidence between those pulses and the most voluminous episodes of the APVC ignimbrite flare-up, (mainly $>500$ up $2,200 \mathrm{~km}^{3}$, DRE) and the megacalderas of southern Puna located respectively 200-300 km west to northwest and $300 \mathrm{~km}$ southsouthwest of the study region. So, in terms of ages and proximity the APVC and southern Puna calderas are the most likely sources of the ash fall tuffs recorded in Humahuaca and Casa Grande basins.

The age clusters that correspond to the two eruptive pulses are not only concordant with regionally recognized pulses of ignimbrite eruptions in the APVC and in the southern Puna, but also with the tectonic events that resulted in basin isolation and paleogeographic changes by $c a$. 4.2- 4.8 Ma, 2.1-1.8 Ma, 0.8 Ma (Pingel et al., 2014; Streit et al., 2015; Pingel et al., 2020).

\subsection{Origin and dispersion of the distal ashes}

Distal ashes may have been derived from the eruption column of large plinian eruptions (co-plinian ash) 


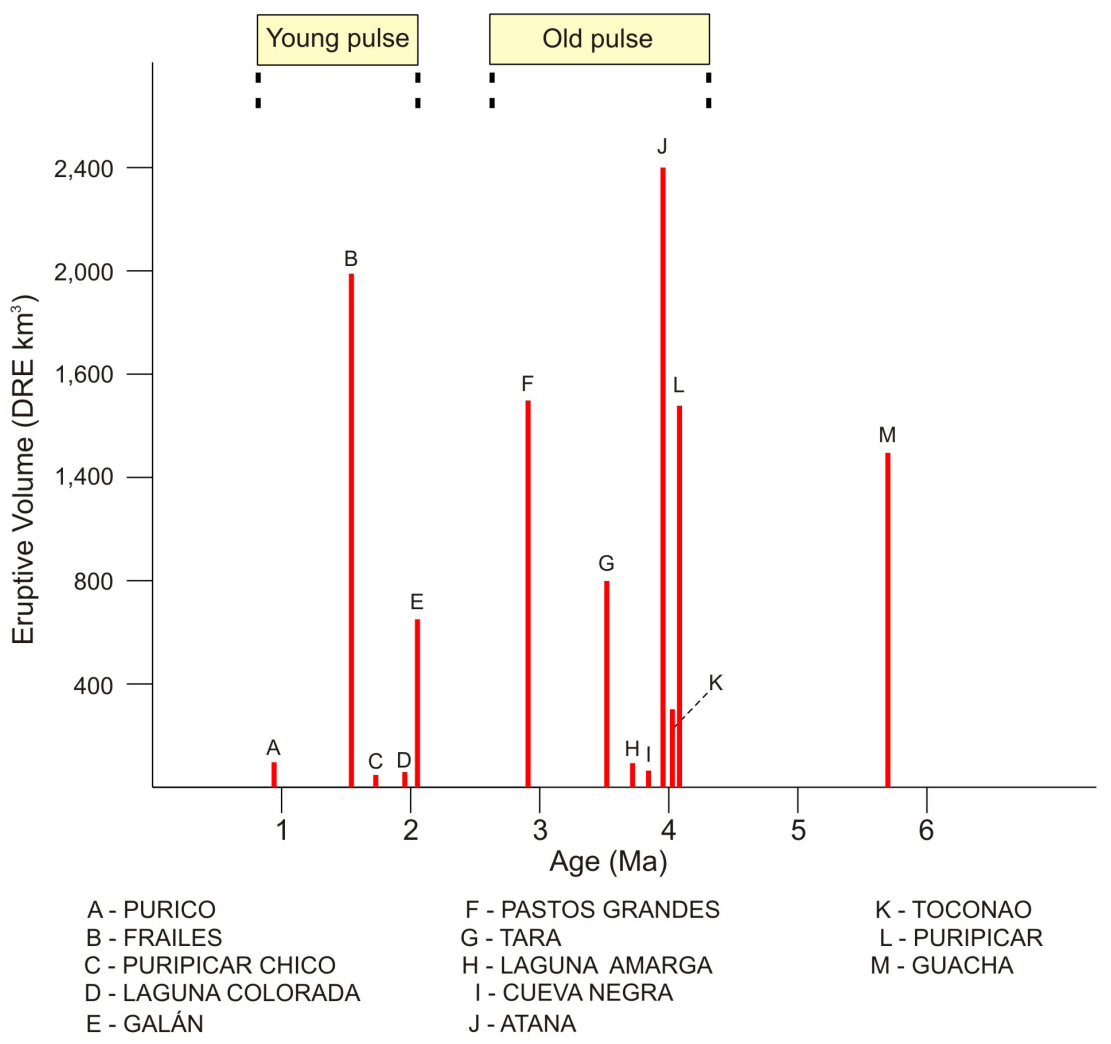

FIG. 11. Volume-time relations plot of Altiplano-Puna volcanic complex and southern Puna ignimbrites for the time span of the pulses recognized in Humahuaca and Casa Grande basins.

or from ash-clouds elutriated from pyroclastic density currents (co-ignimbrite ash) (Walker, 1971; Wilson, 1976; Sparks and Walker, 1977; Chesner et al., 1991). In the case of the distal ashes deposited in Huamhuaca and Casa Grande basins we lean, as Breitkreuz et al. (2014) in the study of Neogene to Quaternary ash deposits of the Coastal Cordillera in northern Chile, towards the co-ignimbrite origin, mainly based on the general lack of basal plinian fall or intraplinian fall units in the ignimbrites of the APVC. In support of this possible origin, although it has considered that the pyroclastic density currents that deposited the large ignimbrites of the APVC were dense, poorly inflated and sluggish (Ort, 1993; de Silva et al., 2006) and that elutriation of ash to feed large co-ignimbrite ash clouds is not efficient in these flows. The crystal enrichment factor 17-47\% (de Silva and Francis, 1989; Folkes et al., 2011) suggests that ash loss through elutriation has likely occurred.
The amount of elutriated material resulted from large eruptions has been estimated by different authors (e.g., Bursik and Woods, 1996) in the order of $20 \mathrm{wt} \%$, although Sparks and Walker (1977) and Mason et al. (2004) suggest that co-ignimbrite ash may constitute as much volume as the outflow ignimbrite itself. These estimates agree with large thickness up to $1.5 \mathrm{~m}$ of some of the studied distal ash fall tuffs (see Table 1).

The dispersion of these ashes around the volcanic region was tightly controlled by dominant geostrophic winds and topography. Ashes from historic eruptions as Lascar Volcano, northern Chile (Glaze et al., 1989), and from Miocene Ramadas Volcanic Complex, Puna (Viramonte et al., 1994) have been dispersed by northwesterly winds, as other examples of the Southern Central Volcanic Zone (SCVZ). In this sense, important ash-fall records recognized in Upper Cenozoic deposits distributed marginally to the high plateau of the Puna and intermountain 


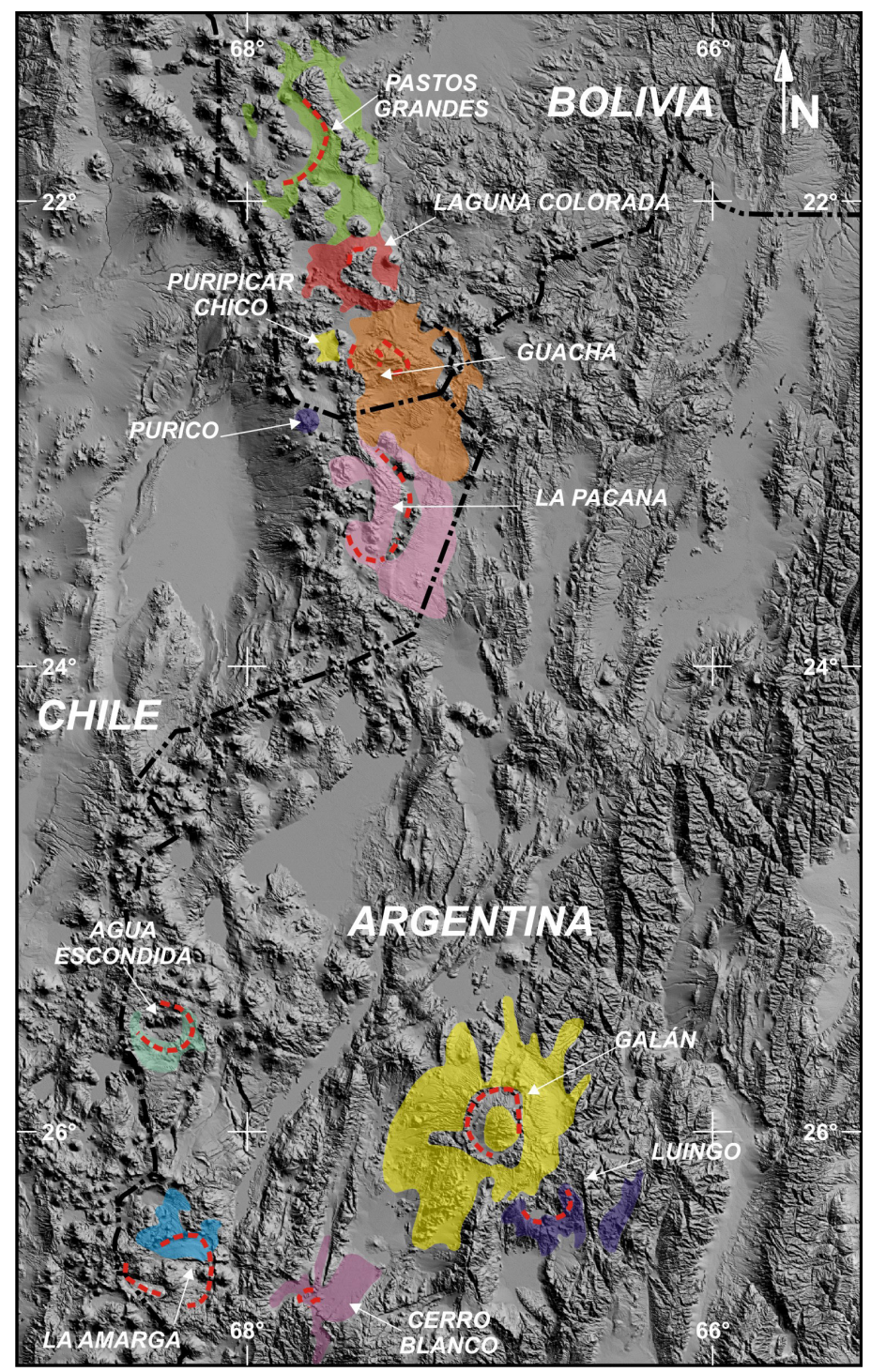

FIG. 12. Satellite Radar Topography Mission (SRTM) image of the Sothern Central Andean region showing main Cenozoic giant calderas evaluated as possible sources of the studied tuffs.

basins as Humahuaca and Casa Grande could be the result of eruptions from volcanic centers located northwesterly and westerly in the SCVZ, that belong to the Altiplano Puna Volcanic Complex (APVC).

\subsection{Potential volcanic sources-correlations}

Considering the contemporaneity and proximity among the APVC and southern Puna conspicuous calderas (Fig. 12) with the Pliocene-Pleistocene ash-fall tuffs of Humahuaca and Casa Grande basins, these centers represent the most likely sources for them. In order to adjust this correlation and to evaluate the potential sources of origin of the tuffs, their mineralogical and chemical composition was compared (Table 4) with those determined in the ignimbrites products of different calderas of the APVC and of the southern Puna, of similar age (Wörner et al., 1992, 1994, 2000; Schröder and Wörner, 1996; de Silva 1989a, b; Lindsay et al., 2001; Schmitt et al., 2001; Mamani et al., 2010; Folkes et al., 2011; Kay et al., 2010, 2011; Salisbury et al., 2011, and references therein). 


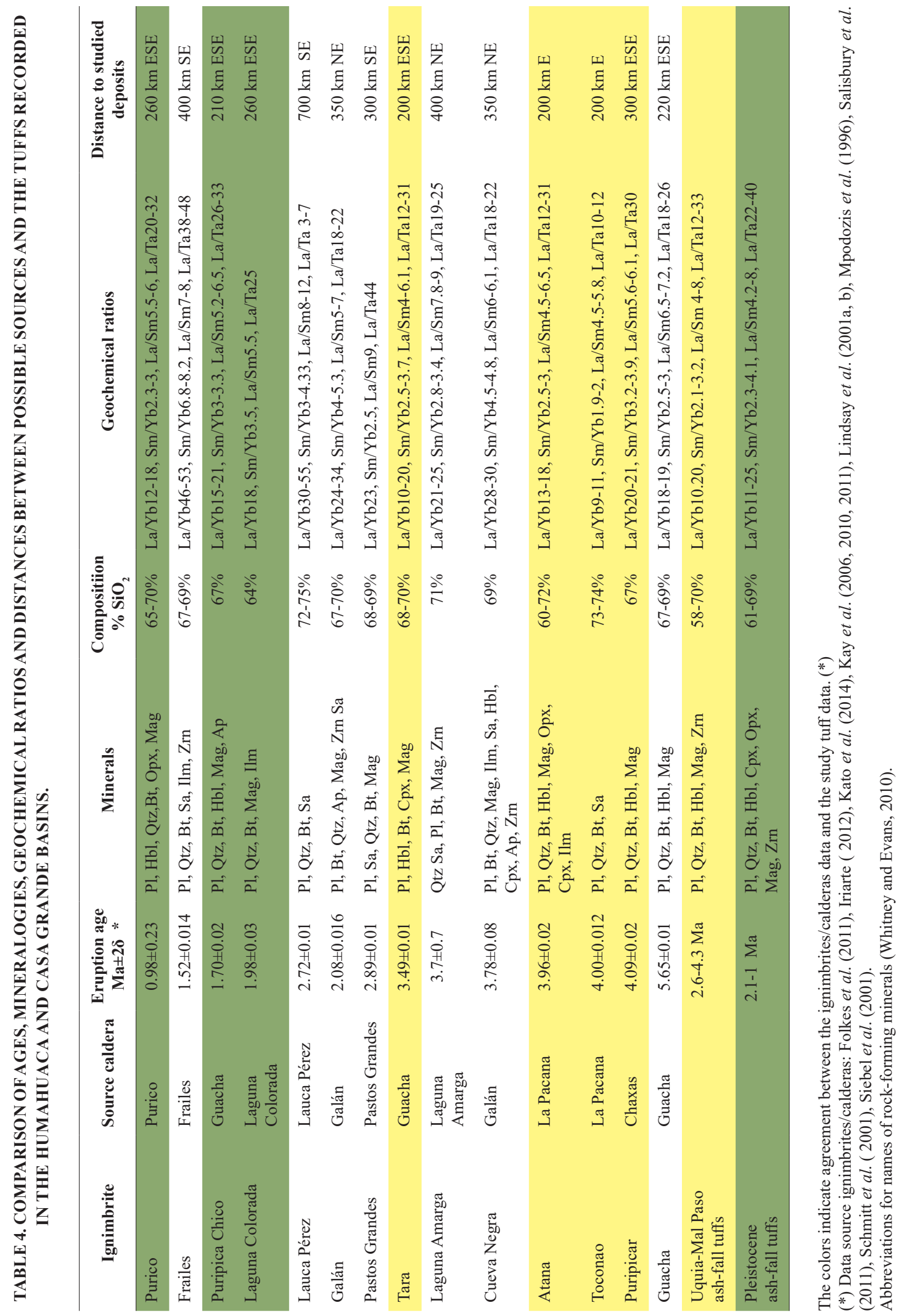


In this comparison, the geochemical data on whole rock were considered, both in the case of tuffs and reference ignimbrites. Although the usual methodology particularly in the study and correlation of proximal and distal ashes contemplates analysis of major element composition of glass shards by EPMA and SEM (Westgate and Gorton, 1981; Froggatt, 1983; Nakagawa and Ohba, 2002; Harangi et al., 2005; Lowe, 2011), it do not always show efficiency in their distinction and correlation, as indicated in cases by the similar composition of tephras produced by different eruptions (Larsen and Eiriksson, 2007; Brendryen et al., 2010; Stokes and Lowe, 1988; Hermanns and Scellenberger, 2008) or by the great compositional variation observed between the glass shards (Breitkreuz et al., 2014).

On the other hand, there are case studies in which correlations of ashes and determination of possible sources have been carried out comparing major and trace-element chemical compositions of bulktephras, with whole rock analysis (mayor and trace elements) of samples belonging to possible source volcanoes (e.g., lavas, ignimbrites), obtaining results of manifest concordance (Naranjo and Stern, 2004; Stern, 2008; Watt et al., 2011). Based on the previous considerations, in order to identify the possible sources of the ash-fall tuffs, major and trace-element chemical compositions of them were compared with those of coeval ignimbrites of APVC and southern Puna calderas, adding to it the identification of their mineral associations.

From this comparative analysis it appears that the age range of Uquía and Mal Paso formations tuffs, that belongs to the older eruptive pulse ( 4.3 to $2.6 \mathrm{Ma}$ ), temporally coincides with the eruption age of ignimbrites from La Pacana and Guacha calderas located $\sim 250 \mathrm{~km}$ to the WNW, as well as from Pastos Grandes caldera at $\sim 300 \mathrm{~km}$ to the NW, from Galán Caldera $\sim 300 \mathrm{~km}$ to the SW and the Laguna Amarga caldera at $\sim 400 \mathrm{~km} \mathrm{SW}$ of the studied ash-fall tuffs outcrops (Fig. 12).

The mineralogical a geochemical characteristics of the Uquía and Mal Paso Formations tuffs (Table 4), correlate well with those of the Atana and Toconao Ignimbrites from La Pacana caldera that yielded zircon $\mathrm{U}-\mathrm{Pb}$ ages for pumice clasts of 4.12 and 4.66 Ma (Schmitt et al., 2001), also with those of the Upper Tara Ignimbrite from Guacha Caldera, that gave ${ }^{40} \mathrm{Ar} /{ }^{39} \mathrm{Ar}$ sanidine and biotite ages of 3.49 and 3.55 Ma, respectively (Salisbury et al., 2011), and with those of the Puripicar Ignimbrite with a ${ }^{40} \mathrm{Ar} /{ }^{39} \mathrm{Ar}$ biotite age of $4.09 \mathrm{Ma}$ (Salisbury et al., 2011). In figure 13 is observed a clear coherence in trace elements ratios within the ranges: $\mathrm{Sm} / \mathrm{Yb}=2-3.8$; $\mathrm{La} / \mathrm{Yb}=9-20 ; \mathrm{La} / \mathrm{Sm}=4.2-8 ; \mathrm{La} / \mathrm{Ta}=11-3$ of the tuffs and those coeval ignimbrites erupted from APVC calderas.

Other ignimbrites in the region erupted during the same span of time show marked geochemical differences (Fig. 13). The Pastos Grandes Ignimbrite $(2.89 \pm 0.01 \mathrm{Ma})$ from the Pastos Grandes caldera exhibits moderately higher HREE $(\mathrm{La} / \mathrm{Yb}=23)$ and a higher arc signature $(\mathrm{La} / \mathrm{Ta}=44)$, the Cuevas Ignimbrite $(3.78 \pm 0.08 \mathrm{Ma})$ from Galán caldera has increase in $\mathrm{Sm} / \mathrm{Yb}=4.3-4.8$ indicative of HREE retention in residual garnet in the source, in contrast to HREE signature of Pastos Grandes Ignimbrite, attributed to residual hornblende (Kay et al., 1987; Kay and Mpodozis, 2001), and La Amarga Ignimbrite, from the homonymous caldera, that is more enriched in LREE elements $(\mathrm{La} / \mathrm{Sm}=7-9)$.

Radiometric ages of the young group-tuffs, (2.21-0.8 Ma), intercalated in Pleistocene alluvial fans sheet flood deposits, suggest that these tuffs coincide with the eruption time of calde ras such as Laguna Colorada (Laguna Colorada Ignimbrite $2.05 \pm 0.01 \mathrm{Ma},{ }^{40} \mathrm{Ar} /{ }^{39} \mathrm{Ar}$ biotite) in the Bolivian Altiplano (Salisbury et al., 2011 ), Lauca Pérez (Lauca Pérez Ignimbrite, $2.72 \pm 0.01 \mathrm{Ma},{ }^{40} \mathrm{Ar} /{ }^{39} \mathrm{Ar}$ sanidine) of the Western Cordillera-Altiplano of the ChileBolivia border region (Wörner et al., 2000), Guacha (Puripica Chico Ignimbrite $\left(1.69 \pm 0.06 \mathrm{Ma},{ }^{40} \mathrm{Ar} /{ }^{39} \mathrm{Ar}\right.$ biotite), Purico (Purico Ignimbrite $1.23 \pm 0.35$ and $1.37 \pm 0.6 \mathrm{Ma}$, biotite K-Ar) in the Atacama region (de Silva, 1989b; Salisbury et al., 2011) and Galán (Galán Ignimbrite $2.09 \pm 0.016 \mathrm{Ma},{ }^{40} \mathrm{Ar} /{ }^{39} \mathrm{Ar}$ sanidine) in the southern Puna region (Kay et al., 2011).

On the basis of mineralogical and geochemical data of these mostly Pleistocene ignimbrites (Wörner et al., 1992, 1994, 2000; Schröder and Wörner, 1996; de Silva 1989a, b; Lindsay et al., 2001; Schmitt et al., 2001; Mamani et al., 2010; Folkes et al., 2011; Kay et al., 2010, 2011; Salisbury et al., 2011, and references therein), we compared them with our new data of the young group tuffs to identify potential correlative eruption sources.

Among these ignimbrites, the Purico from the Purico Complex (Schmitt et al., 2001), the Puripica Chico from the Guacha Caldera and the Laguna Colorada from the Laguna Colorada 

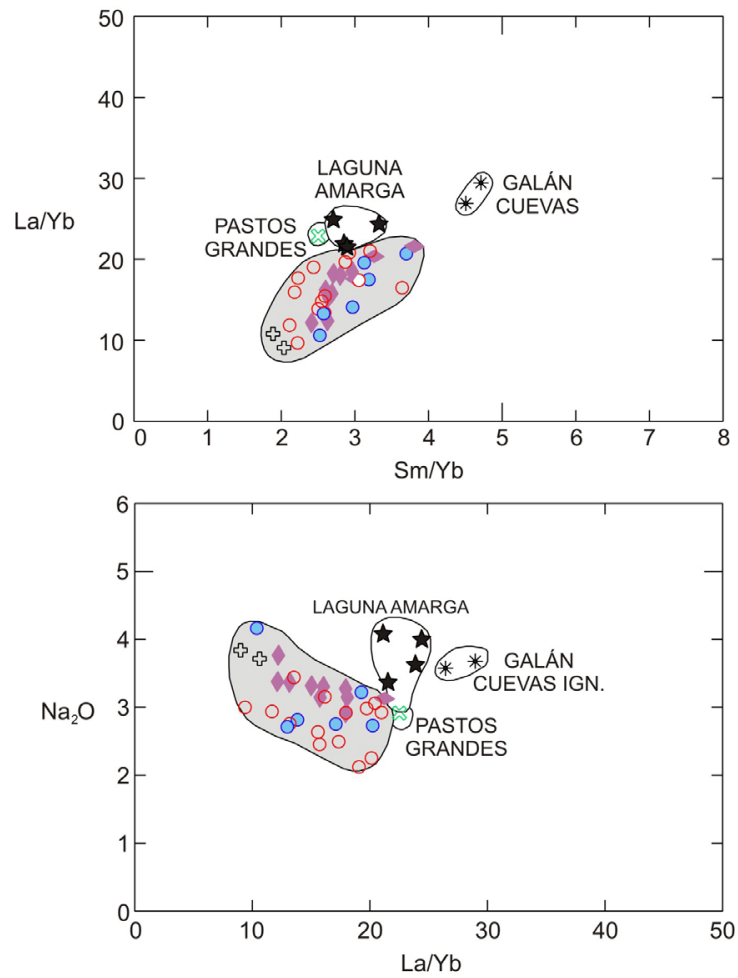
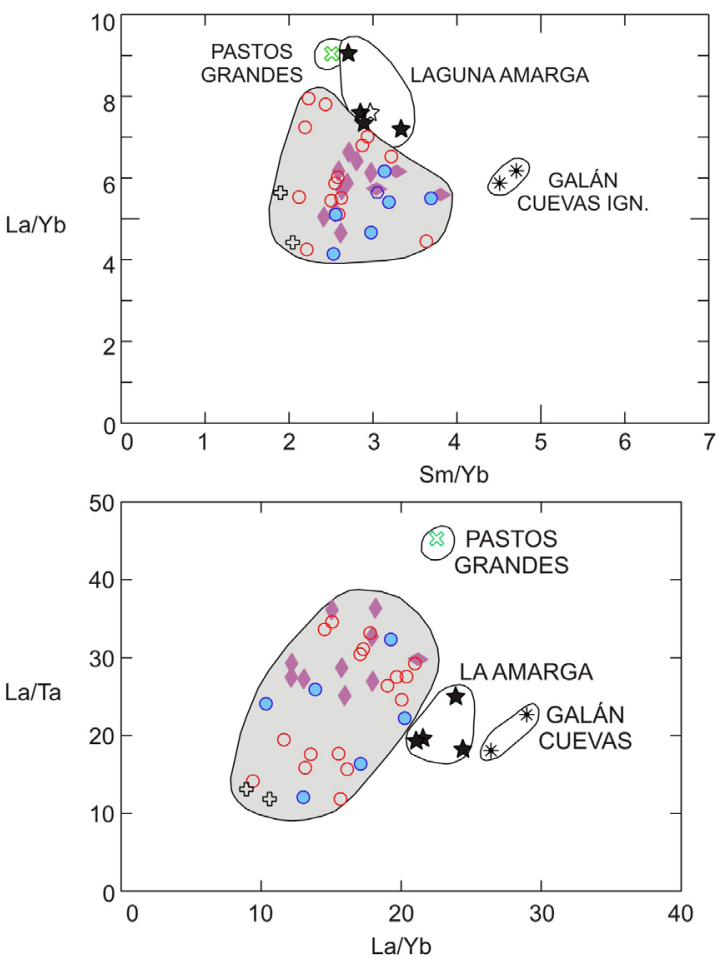

FIG. 13.Trace element plots showing some general chemical features of Uquia and Mal Paso formations tuffs (red circle points correspond to samples in table 2 (A-B) compare with those of potential emission centers as Pastos Grandes, Galán, Laguna Amarga and Altiplano-Puna Volcanic Complex centers APVC $\left(22^{\circ}-24^{\circ} \mathrm{S}\right)$ represented as fields. The Uquia and Mal Paso formations tuffs show trace elements affinities with ignimbrites from APVC like Atana (vertical diamond lila) and Toconao (open cross) ignimbrites from La Pacana caldera, Upper Tara (light blue circle) from Guacha Caldera and Puripicar.(horizontal diamond lila) all of them included in gray field. Data from (Lindsay et al., 2001; Salisbury et al., 2011; Kay et al., 2006 ).

Caldera (Salisbury et al., 2011), located as far as 250-270 km WNW of the studied tephra outcrops (Fig. 12), show strong mineralogical and geochemical similarities (Table 4, Fig. 14), pointing to them as likely potential sources. In contrast, other regional ignimbrites erupted during the same span of time show considerable geochemical differences. The Lauca Pérez Ignimbrite (18.16 S- 69.64 W Western Cordillera-Altiplano Chile-Bolivia) is rhyolitic in composition $\left(72-75 \% \mathrm{SiO}_{2}\right.$ ) compared to daciticrhyodacitic young group of tuffs. It also exhibits a higher degree of enrichment in LREE elements, with $\mathrm{La} / \mathrm{Sm}(8-12)$ and $(\mathrm{La} / \mathrm{Yb}=30-55)$ and very low $\mathrm{La} / \mathrm{Ta}$ (3-7), indicating an intraplate signature (Pearce, 1996) (Fig. 14) as well as a steep REE pattern ( $\mathrm{Sm} /$ $\mathrm{Yb}=3-4.3)$ that requires residual garnet in the source (Kay et al., 1987; Kay and Kay 1991). While having similar $\mathrm{SiO}_{2}$ content $(66-70 \%)$, the Frailes Ignimbrites differs in HREE content with high $\mathrm{Sm} / \mathrm{Yb}$ (7-8.5) ratios pointing to the presence of garnet in the source (Kay et al.,1987; Kay and Kay, 1991) and higher La/Ta (35-48) suggesting an arc signature (Pearce, 1982; Pearce and Peate, 1995). The dacitic to rhyodacitic Galán Ignimbrite (Fig. 14) shows lower $\mathrm{Sm} / \mathrm{Yb}=4$ 5.5 ratios than the Frailes Ignimbrite, but is also characterized by a HREE signatures indicative of residual garnet, which contrasts with the lower $\mathrm{Sm} /$ $\mathrm{Yb}=2-3.5$ ratios of the young group of tuffs that are suggestive of residual hornblende (Kay and Mpodozis, 2001). The $\mathrm{La} / \mathrm{Ta}$ (16-25) of Galán Ignimbrite is also lower than those determined for young tuffs (Fig. 14).

The temporal, mineralogical and geochemical correlations observed among the ash fall tuffs deposited in the Humahuaca and Casa Grande basins and APVC ignimbrites highlight "the distinctive signature" of the APVC, which can be recognized in the distal ash fall tuffs. That "distinctive signature" recognized in the APVC is in accordance with the 

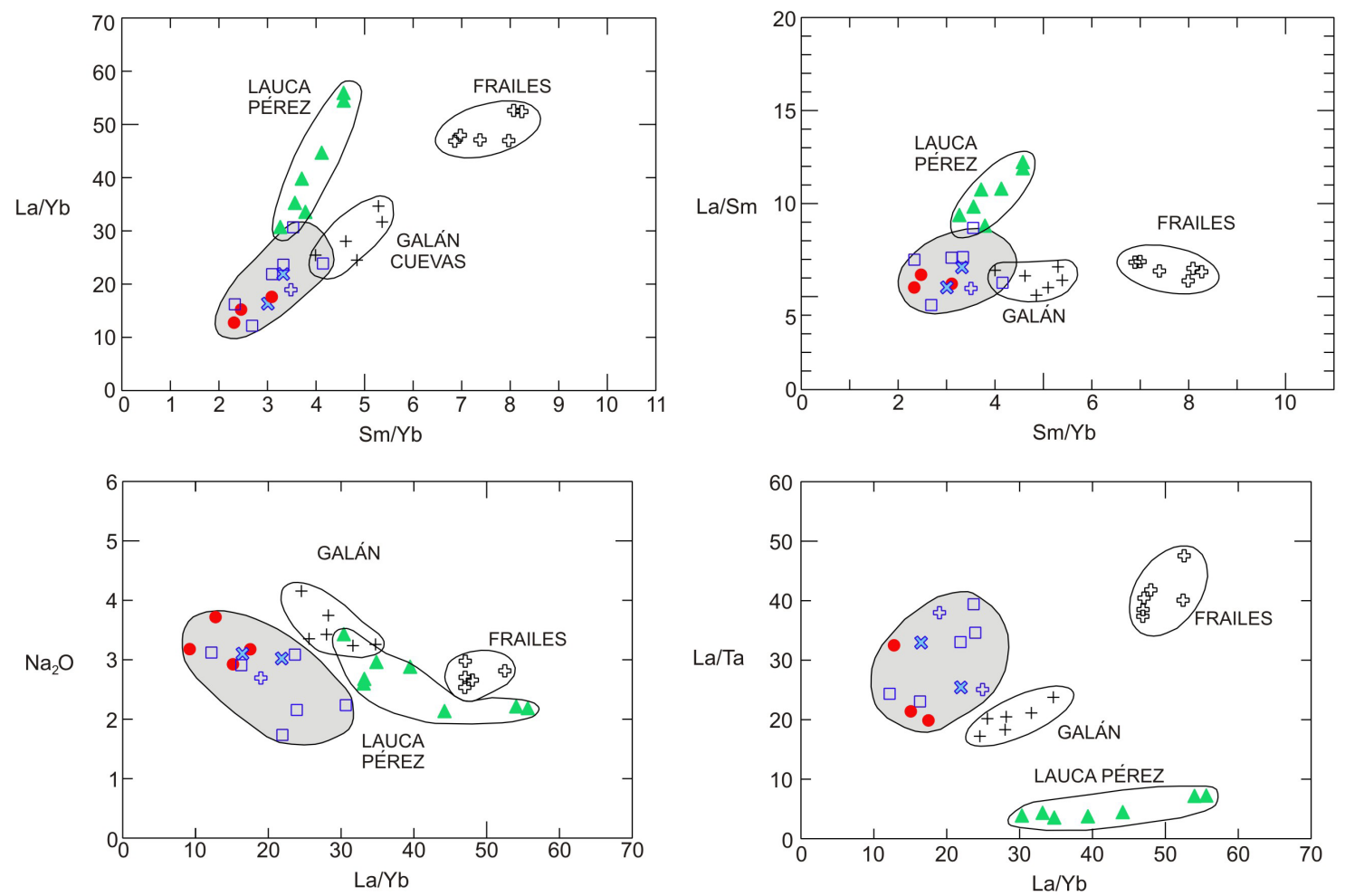

FIG 14. Trace element plots showing some general chemical features of tuffs from Pleistocene alluvial fans sheet flood deposits (blue square points correspond those samples in Table 2B*) compare with those of potential emission centers as Frailes, Galán, Lauca Pérez, Altiplano-Puna Volcanic Complex centers APVC $\left(22^{\circ}-24^{\circ} \mathrm{S}\right)$ represented as fields. The Alonso Formation tuffs show trace elements affinities with ignimbrites from APVC like Purico (red circle) from Purico Complex, Puripica Chico (X light blue) from Guacha Caldera and Laguna Colorada (open cruz), from Laguna Colorada Caldera, all of them included in gray field Data from (Salisbury et al., 2011; Schmitt et al., 2001).

recognition of the "regional geochemical trends" of the Andean ignimbrites according location and time, as have been reported in previous studies (Kay and Coira, 2009; Mamani et al., 2010; Brandmeier and Wörner, 2016 and references therein). These ignimbrites have distinctive compositional characteristics at the regional level linked to basement differences, along with temporal changes in that basement, thermal and structural evolution of the crust, distinct regimes of partial crustal melting and mantle melt compositions, evolved over a changing variable steepening subduction zone (de Silva, 1989a; Coira et al., 1993; Ort et al., 1996; Kay et al., 1999; Lucassen et al., 2000; Lindsay et al., 2001; Zandt et al., 2003; Sobolev and Babeyko, 2005; Trumbull et al., 2006; de Silva and Gosnold, 2007; Schnurr et al., 2007; Kay and Coira, 2008, 2009; Kay et al., 2010, 2011; Folkes et al., 2011; Guzman et al., 2014 and references therein).

\section{Conclusions}

Ash-fall tuffs of the Pliocene-Pleistocene deposits of Humahuaca and Casa Grande intermountain basins, northwestern Argentina have been differentiated into two distinctive groups based on new mineralogical, geochemical and geo-chronological data, which correspond to the tuffs recorded in Pliocene alluvial fan deposits dominated by debris flow, deep sandy gravel braided, and shallow ephemeral lake deposits and in those tuffs recorded in Pleistocene alluvial fans sheet flood deposits.

The distinctive characteristics determined for these ash fall tuffs points to these as excellent chronostratigraphic tracers of the Pliocene-Pleistocene stratigraphy of the Humahuaca and Casa Grande intermountain basins.

The two clusters of ages identified: 4.3 to 2.6 $\mathrm{Ma}$, and 2.2-pre 0.8 Ma, corresponding to the tuff 
groups, were recognized as coeval with ignimbrite eruptions pulses of Altiplano Puna Volcanic Complex (APVC), and southern Puna calderas, located to 200-300 km west-northwest and to $350 \mathrm{~km}$ south of the study region respectively.

Detailed petrographic, geochemical, and geochronological comparison among those ignimbrites, potential sources according age and proximity with the studied ash fall tuffs, highlighted the "distinctive signature" indicative of the regional compositional trend of the APVC, which can be recognized in the distal ash fall deposits.

The old group of tuffs shows affinity with those ignimbrites erupted from the most voluminous calderas of the APVC, like La Pacana (Atana and Toconao ignimbrites) Guacha (Upper Tara Ignimbrite) and Chaxas dome complex (Puripicar Ignimbrite). The young group of tuffs show greater agreement with the ignimbrites erupted from Purico Complex (Purico Ignimbrite), Guacha Caldera (Puripica Chico Ignimbrite), and the Laguna Colorada Caldera (Laguna Colorada Ignimbrite) during the Pleistocene waning stage of the APVC. The affinities observed were not detected for an exclusive center, but for several centers of the APVC, active during the recognized pulses, indicating the importance of the regional compositional signatures of magmatic complexes of the magnitude of the APVC, in order to identify potential magmatic sources of distal ash fall tuffs.

\section{Acknowledgments}

This research was funded by the AGENCIA (PICT2017-1010), PUE-INECOA (22920170100027CO), CI-UNSa 2013-2287 and SECTER-UNJu 08/E036-E0035. We thank Dr. J.A. Naranjo and Dr. I. Petrinovic for the positive suggestions that improved this research. We also thank A.J. Pérez for his invaluable collaboration in the field survey and sample processing, as well as for his constructive and positive suggestions, R. Liquin and P. Cachizumba for their extensive support in laboratory work and E.D. González for his efficient assistance with graphics and illustrations.

\section{References}

Benowitz, J.A.; Layer, P.W.; Vanlaningham, S. 2014. Persistent long-term ( $c a .24 \mathrm{Ma}$ ) exhumation in the Eastern Alaska Range constrained by stacked thermochronology. In Advances in ${ }^{49} \mathrm{Ar} /{ }^{39} \mathrm{Ar}$ dating from archeology to planetary science (Jourdan, F.;
Mark, D.F.; Verati, C.; editors). Geological Society of London, Special Publications 378 (1): 225-243.

Brandmeier, M.; Wörner, G. 2016. Compositional variations of ignimbrite magmas in the Central Andes over the past $26 \mathrm{Ma}$, a multivariate statistical perspective. Lithos 262: 713-728.

Breitkreuz, Ch.; de Silva, S.L.; Wilke, H.G.; Pfänder, J.A.; Renno, A.D. 2014. Neogene to Quaternary ash deposits in the Coastal Cordillera in northern Chile: Distal ashes from supereruptions in the Central Andes. Journal of Volcanology and Geothermal Research 269: 68-82.

Brendryen, J.; Haflidason, H.; Sejrup, H.P. 2010. Norwegian Sea tephrostratigraphy of marine isotope stages 4 and 5: prospects and problems for tephrochronology in the North Atlantic region. Quaternary Science Reviews 29: 847-864.

Bursik, M.I.; Woods, A.W. 1996. The dynamics and thermodynamics of large ash flows. Bulletin of Volcanology 58: 175-193.

Castellanos, A. 1950. El Uquiense. Sedimentos neógenos de Uquia (Senador Pérez) de la Provincia de Jujuy (Argentina). Facultad Ciencias Matemáticas, FísicoQuímica y Naturales de la Universidad Nacional del Litoral, Publicación 36: 1-55.

Coira, B.; Kay, S.M; Viramonte, J. 1993. Upper Cenozoic magmatic evolution of the Argentine Puna-A model for changing subduction geometry. International Geology Review 35: 677-720

Chesner, C.A.; Rose, W.I.; Deino, A.; Drake, R.; Westgate, J.A. 1991. Eruptive history of Earth's largest Quaternary caldera (Toba, Indonesia) clarified. Geology 19: 200-203.

de Silva, S.L. 1989a. The Altiplano-Puna Volcanic Complex of the Central Andes. Geology 73: 1102-1106.

de Silva, S.L. 1989b. Geochronology and stratigraphy of the ignimbrites from the $21^{\circ} 30^{\prime} \mathrm{S}$ to $23^{\circ} 30^{\prime} \mathrm{S}$ portion of the Central Andes of northern Chile. Journal of Volcanology and Geothermal Research 37: 93-131.

de Silva, S.L.; Francis, P.W. 1989. Correlation of large volume ignimbrites-two case studiesfrom the Central Andes of N. Chile. Journal of Volcanology and Geothermal. Research 37: 133-149.

de Silva, S.L.; Gosnold, W.A. 2007. Episodic construction of batholiths: insights from the spatiotemporal development of an ignimbrite flare-up. Journal of Volcanology and Geothermal Research 167: 320-335.

Fernández, J.; Bondesio P.; Pascual, R. 1973. Restos de Lepidosiren paradoxa (Osteichthyes, Dipnoi) de la Formación Lumbrera (Eoceno, ¿Eogeno?) de Jujuy. Ameghiniana 10: 152-171. 
Folkes, C.B.; de Silva, S.; Wright, H.M.; Cas, R.A.F. 2011. Geochemical homogeneity of a long-lived large silicic system: evidence from Cerro Galán Caldera, NW Argentina. In The Cerro Galán Ignimbrite and Caldera: characteristics and origins of a very large volume ignimbrite and its magma system (Cas, R.A.F.; Cashman, K.; editors). Bulletin of Volcanology, Special Issue 73: 1455-1486. New York.

Froggatt, P.C. 1983. Toward a comprehensive Upper Quaternary tephra and ignimbrite stratigraphy in New Zealand using electron microprobe analysis of glass shards. Quaternary Research 19: 188-200.

Galli, C.I.; Coira, L.B.; Candela, A.M.; Alonso, R.N.; Reguero, M.; Abello, M. A.; De los Reyes, M.; Voglino, D.I. 2012. Los depósitos del Mioceno superiorPleistoceno de la Quebrada de Humahuaca, provincia de Jujuy. In Simposio de Mioceno-Pleistoceno del Centro y Norte de Argentina, No. 1, Ameghiniana 49 (4): R-10. San Miguel de Tucumán.

Galli, C.I.; Alonso, R.N.; Coira, B.; Herrera Oviedo, P. 2017. Las Cuencas de Antepaís Cenozoicas de Cordillera Oriental, Noroeste Argentino. In Congreso Geológico Argentino, No. 20, Relatorio: 213-240. San Miguel de Tucumán.

Galli, C.I.; Coira, B.; Alonso, R.N.; Stockli, D.; Herrera Oviedo, P.; González, E.D. 2019. La cuenca intermontana de Humahuaca y sus depósitos del Plioceno-Pleistoceno, provincia de Jujuy. In Simposio del Mioceno Pleistoceno del Centro y Norte de Argentina, No. 5, Actas: 196 p. San Salvador de Jujuy.

Glaze, L.S.; Francis, P.W.; Self, S.; Rothery, D.A. 1989. The Lascar September 16, 1986 eruption: Satellite Investigations. Bulletin of Volcanology 51: 149-160.

Gorton, M.P.; Schandl, E.S. 2000. From continents to island arcs: a geochemical index of tectonic setting for arcrelated and within-plate felsic to intermediate volcanic rocks. The Canadian Mineralogist 38: 1065-1073.

Guzmán, S.; Grosse, P.; Montero-López, C.; Hongn, F.; Pilger, R.; Petrinovic, I.A.; Seggiaro, R.; Aramayo, A. 2014. Spatial-temporal distribution of explosive volcanism in the $25-28^{\circ} \mathrm{S}$ segment of the Andean central volcanic zone. Tectonophysics 636: 170-189.

Harangi, S.; Mason, P.R.D.; Lukacs, R. 2005. Correlation and petrogenesis of silicic pyroclastic rocks in the northern Pannonian Basin, eastern-central Europe: in situ trace element data of glass shards and mineral chemical constraints. Journal of Volcanology and Geothermal Research 143: 237-257.

Hermanns, R.L.; Schellenberger, A. 2008. Quaternary tephrochronology helps define conditioning factors and triggering mechanisms of rock avalanches in NW Argentina. Quaternary International 178: 261-275.

Herrera Oviedo, P.; Galli, C.I.; Console Gonella, C.; Coira, B.L; Alonso, R.N. 2017. Estructuras de deformacion sinsedimentarias de los depósitos del Mioceno superior-Pleistoceno de la Quebrada de Humahuaca, Provincia de Jujuy. In Congreso Geológico Argentino "Geología, Presente y Futuro", No. 20 y Simposio del Mioceno Pleistoceno del centro-norte Argentina, No. 4: 58-59. Tucumán.

Kay, R.W.; Kay, S.M. 1991. Creation and destruction of lower continental crust: Geologische Rundschau 80: 259-278.

Kay, S.M.; Mpodozis, C. 2001. Central Andean ore deposits linked to evolving shallow subduction systems and thickening crust. Geological Society of America Today 11: 4-9.

Kay, S.M.; Coira, B.L. 2008. Implications of chemical and isotopic variations in Neogene Puna plateau ignimbrites for Central Andean crustal evolution. Geochimica et Cosmochimica Acta 72: A456.

Kay, S.M.; Coira, B. 2009. Shallowing and steepening subduction zones, continental lithospheric loss, magmatism and crustal flow under the Central Andean Altiplano-Puna plateau. In Backbone of the Americas: Shallow Subduction, Plateau Uplift and Ridge Collision (Kay, S.M.; Ramos, V.A.; Dickinson, W.R.; editors). The Geological Society of America Memoir 204: 229-258.

Kay, S.; Maksaev, V.; Mpodozis, C.; Moscoso, R.A; Nasi, C. 1987. Probing the evolving Andean lithosphere; Mid-late Tertiary magmatism in Chile $\left(29-30.5^{\circ} \mathrm{S}\right)$ over the zone of subhorizontal subduction. Journal of Geophysical Research 92: 6173-6189.

Kay, S.M.; Mpodozis, C.; Coira, B. 1999. Magmatism, tectonism and mineral deposits of the Central Andes $\left(22^{\circ}-33^{\circ} \mathrm{S}\right.$ latitude). In Geology and ore deposits of the central Andes (Skinner, B.J.; editor). Society of Economic Geologists, Special Publication 7: 27-59.

Kay, S.M.; Coira, B.; Mpodozis, C. 2006. Late Neogene volcanism in the Cerro Blanco region of the Puna Austral Argentina, $\left(\sim 26.5^{\circ} \mathrm{S}, \sim 67.5^{\circ} \mathrm{W}\right)$. In Congreso Geológico Chileno, No. 11, Actas 2: 499-502. Antofagasta.

Kay, S.M.; Coira, B.L.; Caffe, P.J. 2010. Regional chemical diversity, crustal and mantle sources and evolution of Puna Plateau ignimbrites in the Central Andes. Journal of Volcanology and Geothermal Research 198: 81-111.

Kay, S.M.; Coira, B.; Wörner, G.; Kay, R.W.; Singer, S. 2011. Geochemical, isotopic and single crystal ${ }^{40} \mathrm{Ar} /{ }^{39} \mathrm{Ar}$ age constraints on the evolution of 
the Cerro Galán Ignimbrites. In Understanding a supervolcano: the Cerro Galán Caldera and its deposits, Northwestern Argentina (Cashman, K.; Cas, R.; editors). Bulletin of Volcanology, Special Issue 73: 1487-1511. doi: 10.1007/s00445-010-0410-7

Kern, J.M.; de Silva, S.L.; Schmitt, A.K.; Kaiser, J.F.; Rodrigo Iriarte, A.; Economos, R. 2016. Geochronological imaging of an episodically constructed subvolcanic batholith: $\mathrm{U}-\mathrm{Pb}$ in zircon chronochemistry of the Altiplano-Puna Volcanic Complex. Geosphere 12 (4): 1054-1077. doi: 10.1130/GES01258.1.

Larsen, G.; Eiríksson, J. 2007. Late Quaternary terrestrial tephrochronology of Iceland-frequency of explosive eruptions, type and volume of tephra deposits. Journal of Quaternary Science 23: 109-120.

Lindsay, J.M.; Schmitt, A.K.; Trumbull, R.B.;de Silva, S.L.; Siebel, W.; Emmermann, R. 2001. Magmatic evolution of the La Pacana caldera system, Central Andes, Chile: compositional variation of two cogenetic, large-volume felsic ignimbrites. Journal of Petrology 42: 459-486.

Lowe, D.J. 2011. Tephrochronology and its application: a review. Quaternary Geochronology 6 (2): 107-153.

Lucassen, F.; Becchio, R.; Wilke, H.G.; Thirlwall, M.F.; Viramonte, J.; Franz, G.; Wemmer, K. 2000. ProterozoicPaleozoic development of the basement of the Central Andes $\left(18^{\circ}-26^{\circ}\right)$-a mobile belt of the South American craton. Journal of South American Earth Sciences 13: 1527-1551.

MacFadden, B.J.; Anaya, F.; Argollo, J. 1993. Magnetic polarity stratigraphy of Inchasi: a Pliocene mammalbearing locality from Bolivian Andes deposited just before the Great American Interchange. Earth and Planetary Science Letters 14: 229-241.

Mamani, M.; Wörner, G.; Sempere, T. 2010. Geochemical variations in igneous rocks of the Central Andean orocline $\left(13^{\circ} \mathrm{S}\right.$ to $\left.18^{\circ} \mathrm{S}\right)$ : Tracing crustal thickening and magma generation through time and space. Geological Society of America Bulletin 122 (1-2): 162-182. doi: 10.1130/B26538.1.

Marshall, L.G.; Butler, R.F.; Drake, R.E. ; Curtis, G.H. 1982. Geochronology of Type Uquian (Late Cenozoic) land mammal age, Argentina. Science 216 (4549): 986- 989.

Mason, B.G.; Pyle, D.M.; Oppenheimer, C. 2004. The size and frequency of the largest explosive eruptions on Earth. Bulletin of Volcanology 66: 735-748.

McDougall, I.; Harrison, T.M. 1999. Geochronology and Thermochronology by the ${ }^{40} \mathrm{Ar} /{ }^{39} \mathrm{Ar}$ Method, $2^{\text {nd }}$ ed., Oxford University Press: 260 p. New York.

McPhie, J.; Doyle, M.; Allen, R. 1993. Volcanic Textures. A guide to the interpretation of textures in volcanic rocks. Centre for Ore Deposit and Exploration Studies. University of Tasmania: 196 p. Tasmania.

Miyashiro, A. 1974. Volcanic rock series in island arcs and active continental margins. American Journal of Science 274: 321-355.

Nakagawa, M.; Ohba, T. 2002. Minerals in volcanic ash.1: Primary minerals and volcanic glass. Global Environmental Research 6 (2): 41-51.

Naranjo, J.A.; Stern, C.R. 2004. Holocene tephrochronology of the southernmost part $\left(42^{\circ} 30^{\prime}-45^{\circ} \mathrm{S}\right)$ of the Andean Southern Volcanic Zone. Revista Geológica de Chile 31: 225-240.

Ort, M.H. 1993. Eruptive processes and caldera formation in a nested downsag-collapse caldera: Cerro Panizos, central Andes Mountains. Journal of Volcanology and Geothermal Research 56: 221-252.

Ort, M.H.; Coira, B.L.; Mazzoni, M.M. 1996. Generation of a crust-mantle mixture; magmasources and contamination at Cerro Panizos central Andes. Contributions to Mineralogy and Petrology 123: 308-322.

Paton, C.; Woodhead, J.D.; Hellstrom, J.C.; Hergt, J.M.; Greig, A.; Maas, R. 2010. Improved laser ablation $\mathrm{U}-\mathrm{Pb}$ zircon geochronology through robust downhole fractionation correction. Geochemistry, Geophysics, Geosystems 11: Q0AA06. doi: 10.1029/2009GC002618.

Pearce, J.A. 1982. Trace element characteristics of lavas from destructive plate boundaries. In Andesites: Orogenic Andesites and Related Rocks (Thorpe, R.S.; editor). John Wiley and Sons: 525-548. London.

Pearce, J.A. 1996. A user's guide to basalt discrimination diagrams. In Trace Element Geochemistry of Volcanic Rocks (Wyman, D.A.; editor). Geological Association of Cananada, Short Course Notes 12: 79-114.

Pearce, J.A.; Peate, D.W. 1995. Tectonic implications of the composition of volcanic arc magmas. Annual Review of Earth and Planetary Sciences 23: 251-285.

Pearce, N.J.G.; Eastwood, W.J.; Westgate, J.A.; Perkins, W.T. 2002. Trace-element composition of single glass shards in distal Minoan tephra from SW Turkey. Journal of the Geological Society 159: 545-556.

Pearce, N.J.G.; Denton, J.S.; Perkins, W.T.; Westgate, J.A.; Alloway, B.V. 2007. Correlation and characterization of individual glass shards from tephra deposits using trace element laser ablation ICP-MS analyses: current status and future potential. Journal of Quaternary Science 22: 721-736.

Petrus, J.; Kamber, B. 2012. Vizual Age: A novel approach to laser ablation ICP-MS U-Pb geochronology data reduction. Geostandards and Geoanalytical Research 36 (3): 247-270. 
Pingel, H.; Strecker, M.R.; Alonso, R.N.; Schmitt, A.K. 2013. Neotectonic Basin and landscape evolution in the Eastern Cordillera of NW Argentina, Humahuaca basin ( 24 $\mathrm{S})$. Basin Research 25: 1-20.

Pingel, H.; Alonso, R.; Mulch, A.; Rohrmann, A.; Sudo, M.; Strecker, M.R. 2014 . Pliocene orographic barrier uplift in the southern Central Andes. Geology 42 (8): 691-694. doi: 10.1130/G35538.1.

Pingel, H.; Strecker, M.; Mulch, A.; Alonso, R.N.; Cottle, J.; Rohrmann, A. 2020. Late Cenozoic topographic evolution of the Eastern Cordillera and Puna Plateau margin in the southern Central Andes (NW Argentina). Earth and Planetary Science Letters 535: 116112. doi: 10.1016/j.epsl.2020.116112.

Reguero, M.A.; Candela, A.M. 2008. Bioestratigrafía de las secuencias neógenas tardías de la Quebrada de Humahuaca, provincia de Jujuy. Implicancias paleoambientales y paleobiogeográficas. In Congreso Geológico Argentino, No. 17, Relatorio: 286-296. San Salvador de Jujuy.

Reguero, M.A.; Candela, A.M.; Alonso, R.N. 2007. Biochronology and biostratigraphy of the Uquía Formation (Pliocene-Early Pleistocene, NW of Argentina) and its significance in the Great American Biotic Interchange. Journal of South America Earth Science 23: 1-16.

Renne, P.R.; Mundil, R.; Balco, G.; Min, K.; Ludwig, K.R. 2010. Joint determination of ${ }^{40} \mathrm{~K}$ decay constants and ${ }^{40} \mathrm{Ar} * /{ }^{40} \mathrm{~K}$ for the Fish Canyon sanidine standard, and improved accuracy for ${ }^{40} \mathrm{Ar} /{ }^{39} \mathrm{Ar}$ geochronology. Geochimica et Cosmochimica Acta 74 (18): 5349-5367.

Salisbury, M.J.; Jicha, B.R.; de Silva, S.L.; Singer, B.S.; Jiménez, N.C.; Ort, M.H. 2011. ${ }^{40} \mathrm{Ar} /{ }^{39} \mathrm{Ar}$ chronostratigraphy of Altiplano-Puna volcanic complex ignimbrites reveals the development of a major magmatic province. Geological Society of America Bulletin 123 (5-6): 821-840.

Schmitt, A.K.;de Silva, S.L.; Trumbull, R.B.; Emmermann, R. 2001. Magma evolution in the Purico ignimbrite complex, northern Chile: evidence for zoning of a dacitic magma by injection of rhyolitic melts following mafic recharge. Contributions to Mineralogy and Petrology 140: 680-700.

Schnurr, W.B.W.; Trumbull, R.B.; Clavero, J.; Hahne, K.; Siebel, W.; Gardeweg, M. 2007, Twenty five million years of silicic volcanism in the southern central volcanic zone of the Andes: Geochemistry and magma genesis of ignimbrites from $25^{\circ}$ to $27^{\circ} \mathrm{S}, 67^{\circ}$ to $72^{\circ} \mathrm{W}$. Journal of Volcanology and Geothermal Research 166: 17-46.
Schröder, W.; Wörner, G.; 1996.Widespread Cenozoic ignimbrites in N-Chile, W-Bolivia and S-Peru, $17^{\circ}-20^{\circ} \mathrm{S} / 71^{\circ}-68^{\circ} \mathrm{W}$. Stratigraphy, extension, correlation and origin. In International Symposium on Andean Geodynamics (ISAG), No. 3, Saint Malo ORSTOM Editions, Collection Colloques et Se'minaires: 645648. Paris.

Sobolev, S.V.; Babeyko, A.Y. 2005. What drives orogeny in the Andes? Geology 33: 617-620.

Sparks, R.S.J.; Walker, G.P.L. 1977. The significance of vitric-enriched air-fall ashes associated with crystalenriched ignimbrites. Journal of Volcanology and Geothermal Research 2: 329-341.

Stacey, J.S.; Kraemer, J.D. 1975. Approximation of terrestrial lead isotope evolution by a two-stage model. Earth and Planetary Science Letters 26: 207-221.

Stern, C.R. 2008. Holocene tephrochronology record of large explosive eruptions in the southernmost Patagonian Andes. Bulletin of Volcanology 70: 435-454.

Stokes, S.; Lowe, D.J. 1988. Discriminant function analysis of late Quaternary tephras from five volcanoes in New Zealand using glass shard major element chemistry. Quaternary Research 30: 270-283.

Streit, R.L.; Burbank, W.D.; Strecker, M.R.; Alonso, R.N.; Cottle, J.M.; Kylander-Clark, A.R.C. 2015. Controls on intermontane basin filling, isolation and incision on the margin of the Puna Plateau, NW Argentina ( $\left.23^{\circ} \mathrm{S}\right)$. Basin Research 1-25. doi: 10.1111/bre.12141.

Sun, S.; McDonough, W.F. 1989. Chemical and isotopic systematics of oceanic basalts: implications for mantle composition and processes. Geological Society, London, Special Publications 42: 313-345. doi: 10.1144/GSL.SP.1989.042.01.19.

Trumbull, R.B.; Riller, U.; Oncken, O.; Scheuber, E.; Munier, K.; Hongn, F.D. 2006. The time-space distribution of Cenozoic volcanism in the south-central Andes: A new data compilation and some tectonic implications. In The Andes, active subduction orogeny (Oncken, O.; Chong, G.; Franz, G.; Giese, P.; Götze, J.; Ramos, V.; Strecker, M.; Wigger, P.; editors). Springer: 29-43. Berlin. doi: 10.1007/978-3-540-48684-8_2.

Vermeesch, P. 2018. IsoplotR: A free and open toolbox for geochronology. Geoscience Frontiers 9 (5): 14791493. doi: 10.1016/j.gsf.2018.04.001.

Viramonte, J.G.; Reynolds, J.H.; del Papa, C.; Disalvo, A. 1994. The Corte Blanco garnetiferous tuff: A distinctive late Miocene marker bed in northwestern Argentina applied to magnetic polarity stratigraphy in the Río Yacones, Salta Province. Earth Planetary Science Letters 121: 519-531. 
Watt, S.F.L.; Pyle, D.M.; Naranjo, J.A.; Rosqvist, G.; Mella, M.; Mather, T.A.; Moreno, H. 2011. Holocene tephrochronology of the Hualaihué region (Andean southern volcanic zone, $\sim 42^{\circ} \mathrm{S}$ ), southern Chile. Quaternary International 246: 324-343.

Walker, J.P.L. 1971. Grain-size characteristics of pyroclastic deposits. The Journal of Geology 79: 696-714.

Walther, A.M.; Orgeira, M.J.; Reguero, M.A.; Verzi, D.H.; Vilas, J.F.; Alonso, R.; Gallardo, E.; Kelley, S.; Jordan, T. 1998. Estudio paleomagnético, paleontológico y radimétrico de la Formación Uquía (Plio-Pleistoceno) en Esquina Blanca (Jujuy). In Congreso Latinoamericano de Geología, No. 10 y Congreso Nacional de Geología Económica, No. 6, Acta 1: p. 77. Buenos Aires.

Westgate, J.A.; Gorton, M.P. 1981. Correlation techniques in tephra studies. In Tephra Studies (Self, S.; Sparks, R.S.J.; editors). Dordrecht Reidel: 73-94. Holland.

Whitney, D.L.; Evans B.W. 2010. Abbreviations for names of rock-forming minerals. American Mineralogist 95: 185-187.

Wilson, L. 1976. Explosive volcanic eruptions III. Plinian eruption columns. Geophysical Journal International 45: 543-556.

Winchester, J.A. Floyd, P.A. 1977. Geochemical discrimination of different magma series and their differentiation products using immobile elements. Chemical Geology 20: 325-343.

Wörner, G.; López-Escobar, L.; Moorbath, S.; Horn, S.; Entenmann, J.; Harmon, R.S.; Davidson, J.D. 1992. Variaciones geoquímicas, locales y regionales, en el arco volcánico Andino del Norte de Chile (17³0’S$22^{\circ} 00$ 'S). Revista Geológica de Chile 19 (1): 37-56. doi: 10.5027/andgeoV19n1-a03.

Wörner, G.; Moorbath, S.; Entenmann, J.; Harmon, R.S.; Davidson, J.D.; López-Escobar, L. 1994. Large geochemical variations along the Andean Arc of northern Chile (17.5-22 $\left.{ }^{\circ} \mathrm{S}\right)$. In Tectonics of the Southern Central Andes. Structure and evolution of an active continental margin (Reutter, K.J.; Scheuber, E.; Wigger, P.J.; editors). Springer-Berlin: 77-91. Berlin.

Wörner, G.; Hammerschmidt, K.; Henjes-Kunst, F.; Lezaun, J.; Wilke, H. 2000. Geochronology $\left({ }^{40} \mathrm{Ar} /{ }^{39} \mathrm{Ar}\right.$, $\mathrm{K}$-Ar, and He-exposure-) ages of Cenozoic magmatic rocks from Northern Chile $\left(18-22^{\circ} \mathrm{S}\right)$ : implications for magmatism and tectonic evolution of the central Andes. Revista Geológica de Chile 27 (2): 205-240. doi: 10.5027/andgeoV27n2-a04.

Zandt, G.; Leidig, M.; Chmielowski, J.; Baumont, D.; Yuan, X. 2003. Seismic detection and characterization of the Altiplano-Puna magma body, Central Andes. Pure and Applied Geophysics 160: 789-807.

Manuscript received: January 06, 2021; revised/accepted: October 27, 2021; available online: January 31, 2022. 


\section{Appendix S1}

TABLE S1. BIOTITE AR/AR DATA.

$\mathbf{L}=$ laser

SR-13B

Weighted average of $\mathrm{J}$ from standards $=8.314 \mathrm{e}-05+/-2.212 \mathrm{e}-07$

\begin{tabular}{|c|c|c|c|c|c|c|c|c|c|c|c|c|c|c|c|c|c|}
\hline $\begin{array}{l}\text { Laser } \\
\text { Power } \\
(\mathrm{mW})\end{array}$ & $\underset{{ }^{39} \mathrm{Ar}}{\text { Cumulative }}$ & $\begin{array}{c}{ }^{40} \mathbf{A r} /{ }^{39} \mathrm{Ar} \\
\text { meas }\end{array}$ & \pm & $\begin{array}{l}{ }^{37} \mathrm{Ar} /{ }^{39} \mathrm{Ar} \\
\text { meas. }\end{array}$ & \pm & $\begin{array}{c}{ }^{36} \mathrm{Ar} /{ }^{39} \mathrm{Ar} \\
\text { meas }\end{array}$ & \pm & $\begin{array}{c}\% \text { Atm. } \\
{ }^{40} \mathrm{Ar}\end{array}$ & \pm & $\mathrm{Ca} / \mathrm{K}$ & \pm & $\mathbf{C l} / \mathbf{K}$ & \pm & ${ }^{40} \mathbf{A r} * /{ }^{39} \mathbf{K}$ & \pm & $\begin{array}{l}\text { Age } \\
\text { (ka) }\end{array}$ & $\begin{array}{c} \pm \\
\text { (ka) }\end{array}$ \\
\hline 500 & 0.008 & 843.560 & 18.790 & 0.016 & 0.033 & 2.759 & 0.067 & 96.656 & 0.926 & 0.029 & 0.060 & 0.039 & 0.003 & 28.207 & 7.850 & $4,221.23$ & $1,173.36$ \\
\hline 1,000 & 0.023 & 326.631 & 4.655 & -0.004 & 0.012 & 1.053 & 0.021 & 95.234 & 1.292 & -0.007 & 0.021 & 0.030 & 0.002 & 15.566 & 4.23 & $2,330.63$ & 632.95 \\
\hline 1,500 & 0.046 & 151.767 & 1.669 & 0.012 & 0.017 & 0.449 & 0.008 & 87.490 & 1.367 & 0.022 & 0.031 & 0.031 & 0.001 & 18.983 & 2.089 & $2,841.92$ & 312.55 \\
\hline 2,000 & 0.077 & 103.569 & 0.973 & 0.003 & 0.007 & 0.300 & 0.007 & 85.507 & 1.854 & 0.006 & 0.013 & 0.032 & 0.001 & 15.006 & 1.926 & $2,246.88$ & 288.22 \\
\hline 2,500 & 0.120 & 80.566 & 0.521 & 0.001 & 0.006 & 0.214 & 0.004 & 78.523 & 1.267 & 0.001 & 0.012 & 0.032 & 0.001 & 17.297 & 1.029 & $2,589.67$ & 154 \\
\hline 3,000 & 0.172 & 70.743 & 0.460 & 0.011 & 0.005 & 0.183 & 0.003 & 76.554 & 1.011 & 0.02 & 0.009 & 0.032 & 0.001 & 16.580 & 0.726 & $2,482.38$ & 108.66 \\
\hline 5,000 & 0.399 & 53.973 & 0.169 & 0.004 & 0.001 & 0.124 & 0.001 & 67.948 & 0.430 & 0.008 & 0.002 & 0.032 & 0.000 & 17.290 & 0.251 & $2,588.63$ & 37.55 \\
\hline 9,000 & 1 & 43.320 & 0.123 & 0.010 & 0.001 & 0.089 & 0.001 & 60.669 & 0.384 & 0.019 & 0.002 & 0.032 & 0.000 & 17.026 & 0.177 & $2,549.19$ & 26.51 \\
\hline Integrated & & 63.682 & 0.119 & 0.008 & 0.001 & 0.157 & 0.001 & 73.104 & 0.272 & 0.015 & 0.002 & 0.032 & 0.000 & 17.120 & 0.178 & $2,563.22$ & 27.53 \\
\hline
\end{tabular}




\section{Appendix S2}

TABLE S2. ZIRCON U-PB LA-ICP-MS DATA.

\begin{tabular}{|c|c|c|c|c|c|c|c|c|c|c|c|c|c|}
\hline Grain \# & {$[\mathbf{U}]$ ppm } & U/Th & ${ }^{207} \mathrm{~Pb} /{ }^{235} \mathbf{U}$ & $2 \sigma$ error & ${ }^{206} \mathbf{P b} /{ }^{238} \mathbf{U}$ & $2 \sigma$ error & RHO & $\begin{array}{l}{ }^{207 P} \mathbf{b}{ }^{2{ }^{235}} \mathbf{U} \\
\text { Age [Ma] }\end{array}$ & $\begin{array}{c}2 \sigma \text { error } \\
{[\mathrm{Ma}]}\end{array}$ & $\begin{array}{l}{ }^{206} \mathrm{~Pb} /{ }^{238} \mathrm{U} \\
\text { Age [Ma] }\end{array}$ & $\begin{array}{c}2 \sigma \text { error } \\
{[\mathrm{Ma}]}\end{array}$ & $\begin{array}{c}\text { Best age } \\
\text { Age [Ma] }\end{array}$ & $\begin{array}{c}2 \sigma \text { error } \\
\text { [Ma] }\end{array}$ \\
\hline MN2_1 & 950 & 1.14 & 0.007 & 0.002 & 0.000 & 0.000 & 0.296 & 7.2 & 2.1 & 3.1 & 0.4 & 3.1 & 0.4 \\
\hline MN2_2 & 617 & 1.34 & 0.002 & 0.001 & 0.000 & 0.000 & 0.087 & 2.4 & 0.8 & 2.1 & 0.2 & 2.1 & 0.2 \\
\hline MN2_3 & 999 & 1.51 & 0.015 & 0.001 & 0.001 & 0.000 & 0.198 & 15.1 & 1.3 & 6.0 & 0.2 & 6.0 & 0.2 \\
\hline MN2_4 & 781 & 1.26 & 0.015 & 0.002 & 0.000 & 0.000 & 0.200 & 14.6 & 1.5 & 2.6 & 0.2 & 2.6 & 0.2 \\
\hline MN2_5 & 1,319 & 1.35 & 0.005 & 0.001 & 0.000 & 0.000 & 0.021 & 5.4 & 0.6 & 2.5 & 0.1 & 2.5 & 0.1 \\
\hline MN2_6 & 1,213 & 1.51 & 0.015 & 0.001 & 0.002 & 0.000 & 0.034 & 15.0 & 1.2 & 13.2 & 0.4 & 13.2 & 0.4 \\
\hline MN2_7 & 387 & 1.21 & 0.061 & 0.004 & 0.001 & 0.000 & 0.174 & 59.7 & 3.8 & 5.3 & 0.4 & 5.3 & 0.4 \\
\hline MN2_8 & 1,910 & 2.03 & 0.011 & 0.001 & 0.001 & 0.000 & 0.292 & 10.7 & 1.3 & 4.3 & 0.2 & 4.3 & 0.2 \\
\hline MN2_9 & 1,861 & 3.10 & 0.004 & 0.000 & 0.000 & 0.000 & 0.005 & 3.8 & 0.4 & 2.9 & 0.1 & 2.9 & 0.1 \\
\hline MN2_10 & 445 & 1.16 & 0.003 & 0.001 & 0.000 & 0.000 & 0.099 & 3.0 & 0.9 & 2.3 & 0.2 & 2.3 & 0.2 \\
\hline MN2_11 & 594 & 1.94 & 0.004 & 0.001 & 0.000 & 0.000 & 0.027 & 4.2 & 0.7 & 2.0 & 0.2 & 2.0 & 0.2 \\
\hline MN2_12 & 356 & 1.47 & 0.029 & 0.004 & 0.001 & 0.000 & 0.087 & 28.7 & 4.3 & 4.2 & 0.4 & 4.2 & 0.4 \\
\hline MN2_13 & 604 & 1.36 & 0.007 & 0.001 & 0.001 & 0.000 & 0.026 & 7.0 & 0.9 & 5.7 & 0.2 & 5.7 & 0.2 \\
\hline MN2_14 & 376 & 2.96 & 0.010 & 0.001 & 0.001 & 0.000 & 0.056 & 9.7 & 1.2 & 4.4 & 0.2 & 4.4 & 0.2 \\
\hline MN2_15 & 1,154 & 1.95 & 0.007 & 0.001 & 0.001 & 0.000 & 0.427 & 7.3 & 1.0 & 6.5 & 0.4 & 6.5 & 0.4 \\
\hline MN2_16 & 861 & 2.86 & 0.014 & 0.001 & 0.002 & 0.000 & 0.094 & 14.5 & 0.9 & 14.2 & 0.4 & 14.2 & 0.4 \\
\hline MN2_17 & 432 & 0.94 & 0.011 & 0.002 & 0.000 & 0.000 & 0.086 & 11.0 & 1.6 & 2.7 & 0.2 & 2.7 & 0.2 \\
\hline MN2_18 & 559 & 1.19 & 0.003 & 0.001 & 0.000 & 0.000 & 0.114 & 2.9 & 0.9 & 2.1 & 0.2 & 2.1 & 0.2 \\
\hline MN2_19 & 1,329 & 1.84 & 0.007 & 0.001 & 0.001 & 0.000 & 0.006 & 6.7 & 0.5 & 5.7 & 0.2 & 5.7 & 0.2 \\
\hline MN2_21 & 853 & 1.19 & 0.004 & 0.001 & 0.000 & 0.000 & 0.107 & 4.3 & 1.1 & 1.9 & 0.2 & 1.9 & 0.2 \\
\hline MN2_22 & 375 & 1.29 & 0.005 & 0.002 & 0.000 & 0.000 & 0.120 & 5.3 & 1.6 & 2.2 & 0.2 & 2.2 & 0.2 \\
\hline MN2_23 & 513 & 1.51 & 0.012 & 0.004 & 0.000 & 0.000 & 0.010 & 12.2 & 4.0 & 2.7 & 0.5 & 2.7 & 0.5 \\
\hline MN2_24 & 141.7 & 0.95 & 0.015 & 0.003 & 0.001 & 0.000 & 0.162 & 14.7 & 2.9 & 9.4 & 0.6 & 9.4 & 0.6 \\
\hline MN2_25 & 527 & 1.27 & 0.006 & 0.001 & 0.001 & 0.000 & 0.011 & 6.1 & 0.9 & 4.7 & 0.2 & 4.7 & 0.2 \\
\hline MN2_26 & 1,002 & 1.12 & 0.005 & 0.001 & 0.001 & 0.000 & 0.037 & 5.0 & 0.6 & 4.0 & 0.2 & 4.0 & 0.2 \\
\hline MN2_27 & 2,640 & 5.24 & 0.010 & 0.000 & 0.001 & 0.000 & 0.208 & 10.2 & 0.5 & 9.1 & 0.2 & 9.1 & 0.2 \\
\hline MN2_28 & 2,300 & 1.66 & 0.007 & 0.001 & 0.001 & 0.000 & 0.049 & 6.9 & 0.5 & 6.3 & 0.2 & 6.3 & 0.2 \\
\hline MN2_29 & 497 & 1.37 & 0.004 & 0.001 & 0.001 & 0.000 & 0.138 & 4.0 & 0.8 & 3.8 & 0.3 & 3.8 & 0.3 \\
\hline MN2_30 & 664 & 1.29 & 0.003 & 0.001 & 0.000 & 0.000 & 0.294 & 3.3 & 0.5 & 2.9 & 0.2 & 2.9 & 0.2 \\
\hline MN2_31 & 816 & 0.89 & 0.005 & 0.001 & 0.000 & 0.000 & 0.090 & 5.1 & 0.9 & 2.2 & 0.1 & 2.2 & 0.1 \\
\hline MN2_32 & 521 & 1.61 & 0.007 & 0.001 & 0.001 & 0.000 & 0.056 & 7.1 & 0.8 & 5.5 & 0.3 & 5.5 & 0.3 \\
\hline MN2_33 & 449 & 1.06 & 0.003 & 0.001 & 0.000 & 0.000 & 0.080 & 3.1 & 0.7 & 2.3 & 0.2 & 2.3 & 0.2 \\
\hline MN2_34 & 463 & 1.76 & 0.020 & 0.002 & 0.003 & 0.000 & 0.192 & 20.1 & 2.2 & 17.8 & 0.9 & 17.8 & 0.9 \\
\hline MN2_35 & 1,630 & 1.11 & 0.003 & 0.001 & 0.000 & 0.000 & 0.282 & 3.5 & 0.6 & 2.1 & 0.1 & 2.1 & 0.1 \\
\hline MN2_36 & 755 & 1.33 & 0.003 & 0.001 & 0.000 & 0.000 & 0.044 & 3.3 & 0.8 & 2.4 & 0.2 & 2.4 & 0.2 \\
\hline MN2_38 & 736 & 2.10 & 0.005 & 0.001 & 0.000 & 0.000 & 0.081 & 4.6 & 0.7 & 2.4 & 0.2 & 2.4 & 0.2 \\
\hline MN2_39 & 201 & 1.54 & 0.006 & 0.001 & 0.001 & 0.000 & 0.141 & 5.9 & 1.4 & 5.1 & 0.4 & 5.1 & 0.4 \\
\hline MN2_40 & 413 & 0.95 & 0.002 & 0.001 & 0.000 & 0.000 & 0.040 & 2.3 & 0.6 & 2.0 & 0.1 & 2.0 & 0.1 \\
\hline
\end{tabular}

